\title{
U-Th chronology and formation controls of methane-derived authigenic carbonates from the Hola trough seep area, northern Norway
}

Simone Sauer, b, * (simone.sauer@uit.no), Antoine Crémière ${ }^{\mathrm{a}, \mathrm{b}, 1}$, Jochen Knies ${ }^{\mathrm{a}, \mathrm{b}}$, Aivo Lepland ${ }^{\text {a, b, d }}$ Diana Sahy ${ }^{\mathrm{c}}$, Tõnu Martma ${ }^{\mathrm{d}}$, Stephen R. Noble ${ }^{\mathrm{c}}$, Jasmin Schönenberger ${ }^{\mathrm{b}}$, Martin Klug ${ }^{\mathrm{b}}$ and Carsten J. Schubert ${ }^{\mathrm{e}}$

aCAGE - Centre for Arctic Gas Hydrate, Environment and Climate, Department of Geosciences, UiT-The Arctic University of Norway, Tromsø, Norway

bThe Geological Survey of Norway, Trondheim, Norway

'British Geological Survey, Keyworth, Nottingham, United Kingdom

dDepartment of Geology, Tallinn University of Technology, Tallinn, Estonia

'Swiss Federal Institute of Aquatic Science and Technology (Eawag), Department of Surface WatersResearch and Management, Kastanienbaum, Switzerland

*Correspondence to: S. Sauer, Département Géosciences Marines, Ifremer, Plouzané, France.

${ }^{1}$ Present address: NASA Jet Propulsion Laboratory, California Institute of Technology, Pasadena, California, United States.

\begin{abstract}
We investigated methane-derived authigenic carbonate (MDAC) crusts and nodules from a cold seep site on the northern Norwegian continental shelf in ca. $220 \mathrm{~m}$ water depth to determine the timing and mode of their formation. Gas bubbling observed during remotely operated vehicle (ROV)-assisted sampling of MDAC crusts revealed ongoing seep activity. Authigenic carbonates were present as crusts on the seafloor and as centimetre-size carbonate-cemented nodules at several intervals within an adjacent sediment core. Aragonite-dominated mineralogy of the MDAC crusts suggests formation close to the seafloor at higher rates of sulphate-dependent anaerobic oxidation of methane (AOM). In contrast, dolomite-cemented nodules are consistent with the formation at the sulphate-methane-transition zone deeper within the sediment at lower rates of AOM. The $\delta^{13} \mathrm{C}$-carbonate values of bulk rock and of micro-drilled aragonite samples vary between - 22.2\% and - 34.6\% (VPDB). We interpret the carbon in aragonite to be mainly derived from the anaerobic oxidation of thermogenic methane, with a minor contribution from seawater dissolved inorganic carbon (DIC). AOM activity is supported by high concentrations of AOM-related biomarkers of archaea (archaeol and 2-sn-hydroxyarchaeol) and sulphate-reducing bacteria (iso and anteiso- $\mathrm{C}_{15: 0}$ fatty acids) in the crusts. The dolomite nodules exhibit higher $\delta^{13} \mathrm{C}$-carbonate values $(-12 \%$ VPDB) suggesting a smaller amount of methane-derived carbon, presumably due to the contribution of DIC migrating from depth, and lower AOM rates. The latter is supported by orders of magnitude lower concentrations of archaeol and sn2-hydroxyarchaeol in the sediment interval containing the largest dolomite nodules. $\delta^{18} \mathrm{O}$ values of pure aragonite samples and dolomite nodules indicate the precipitation of carbonate close to isotopic equilibrium with seawater and no influence of gas hydrate-derived water. U-Th dating of two MDAC crusts shows that they formed between $1.61 \pm 0.02$ and $4.39 \pm 1.63 \mathrm{ka} \mathrm{BP}$ and between $2.65 \pm 0.02$ and $4.32 \pm 0.08 \mathrm{ka} \mathrm{BP}$. We infer both a spatial and temporal change in methane flux and related MDAC formation at this seep site. These changes might be caused by regional seismic events that can affect pore pressure or re-activation of migration pathways thus facilitating fluid flow from deep sources towards the seabed.
\end{abstract}

Keywords: Methane-derived authigenic carbonate; Cold seep; U-Th geochronology; Dolomite nodules; Anaerobic oxidation of methane; Biomarker

\section{Introduction}

Seepage of hydrocarbon-rich fluids is a common feature along continental margins worldwide (Judd and Hovland 2007). High methane fluxes in marine sediments induce high rates of sulphate-dependent anaerobic oxidation of methane (AOM) at the sulphate-methane transition zone (SMTZ). AOM is mediated 
by a symbiotic partnership between anaerobic methanotrophic archaea (ANME) and sulphate-reducing bacteria (SRB) (Hinrichs et al. 1999; Boetius et al. 2000; Orphan et al. 2001) resulting in increased alkalinity in sediment pore waters. Consequently, carbonate precipitation involving $\mathrm{Ca}^{2+}$ and/or $\mathrm{Mg}^{2+}$ from pore water and bicarbonate produced by AOM can form authigenic carbonate crusts, nodules, slabs, chimneys and extensive pavements due to the oversaturation with respect to carbonate minerals (e.g. Ritger et al. 1987; Aloisi et al. 2002; Blumenberg et al. 2015). Such methane-derived authigenic carbonates (MDACs) are preserved at the seafloor or within the sediment column at seep sites even after methane flux has waned and thus form an important archive of long-term seepage history (Watanabe et al. 2008; Feng et al. 2010; Tong et al. 2013; Crémière et al. 2016a). Furthermore, their mineralogy and geochemical and isotopic signatures provide information on the environmental conditions during MDAC formation and potential changes of the ascending fluids over time (Greinert et al. 2001; Moore et al. 2004; Gieskes et al. 2005; Meister et al. 2007; Pierre and Fouquet 2007; Haas et al. 2010). MDACs typically show low $\delta^{13} \mathrm{C}$-carbonate values reflecting the incorporation of carbon derived from AOM (Hovland et al. 1987; Aloisi et al. 2000; Teichert et al. 2005; Crémière et al. 2016b). The link between MDAC formation and anaerobic methane oxidation coupled to sulphate reduction is also indicated by the ubiquitous occurrence of ${ }^{13} \mathrm{C}$-depleted lipid biomarkers characteristic of methanotrophic archaea and SRB (AOM consortia) (Bahr et al. 2009; Chevalier et al. 2010; Feng et al. 2014a; Blumenberg et al. 2015; Himmler et al. 2015).

Modern and ancient MDACs have been studied to deduce information on past methane seepage into the ocean (Aharon et al. 1997; Peckmann and Thiel 2004; Crémière et al. 2013; Berndt et al. 2014) and to delineate their significance as an essential methane-carbon sink (Aloisi et al. 2002; Marlow et al. 2014; Römer et al. 2014; Panieri et al. 2017a). Hence, the reliable dating of seep carbonates and reconstruction of their formation may allow the assessment of factors influencing the seepage such as (1) the source of the sub-seafloor hydrocarbon reservoir, (2) the opening of migration pathways and (3) changes in bottom water temperature or pressure variation related to sea level changes, both of which affect gas hydrate formation/dissociation (e.g. Teichert et al. 2003; Feng et al. 2010). U-Th chronology has so far proven to be the most successful method of dating seep carbonates (e.g. Watanabe et al. 2008; Bayon et al. 2009; Bayon et al. 2013; Crémière et al. 2013; Tong et al. 2013; Berndt et al. 2014; Bayon et al. 2015; Crémière et al. 2016a). For instance, dating of MDACs from the western Svalbard margin at $385 \mathrm{~m}$ water depth revealed U-Th ages of $8.2 \pm 0.5$ and $4.6 \pm 0.5 \mathrm{ka}$ BP (Berndt et al. 2014), challenging the hypothesis that methane seepage was triggered by gas hydrate dissociation at the upper limit of the gas hydrate stability zone due to anthropogenic bottom water warming (Westbrook et al. 2009). In another study, two samples from the continental slope of the South China Sea were dated at 330-152 ka BP and 77-63 ka BP, respectively, establishing a link between methane emission and gas hydrate dissociation due to reduced hydrostatic pressure during times of sea level fall or sea level low stand (Tong et al. 2013). In the Norwegian and Barents Seas MDACs were studied in a variety of settings including pockmark sites, and active and extinct seep sites (Hovland et al. 1985; Hovland et al. 2005; Mazzini et al. 2006; Crémière et al. 2016a; Crémière et al. 2016b; Mazzini et al. 2016). While isotopic characteristics suggested a microbial methane source of MDACs in the Alvheim Channel, central North Sea, a predominantly thermogenic methane source was found in the SW Barents Sea (Crémière et al. 2016a; Crémière et al. 2016b). A study on MDAC crusts and pockmarks above the Troll gas field suggests extensive methane seepage in the past, but no activity at present (Mazzini et al. 2016). Methane seepage in these areas has been related to leakage from thermogenic and microbial sources along deep-seated faults as well as from gas hydrate dissociation (Crémière et al. 2016a; Mazzini et al. 2016), linked to depressurizing effects of the retreating Fennoscandian Ice Sheet after the last glaciation (Crémière et al. 2016a). Furthermore, the dynamics of seeps and/or associated carbonate formation have, at some locations, been tentatively linked to regional tectonic or hydrological changes as, for example, on the accretionary margin off New Zealand and the Central American forearc (Kutterolf et al. 2008; Liebetrau et al. 2010). Earthquakes have been identified as main trigger for fracturing in gas-hydrate bearing sediments leading to hydrocarbon seepage on the convergent margin off Pakistan (Fischer et al. 2013). As described by Fischer et al. (2013) or Hong et al. (2017) a combination of pore water modelling and sediment chemistry data can be used to reconstruct SMTZ fluctuations and both temporal and spatial variability of methane flux. This may allow the interpretation of causative triggers of methane flux variations such as earthquake activity, glacial-interglacial cycles and changes in fluid flow pathways caused by hydrate formation or carbonate precipitation.

In this study, we investigate both MDAC crusts from the seafloor and carbonate nodules from a sediment core in the Hola trough on the northern Norwegian continental shelf (Fig. 1), to reconstruct the history of the hydrocarbon seepage system and the factors influencing it. The aim of the study is to constrain 
the episodes of past methane seepage and changes in methane flux and to determine whether there is a relationship between the deglaciation of the shelf and hydrocarbon seepage.

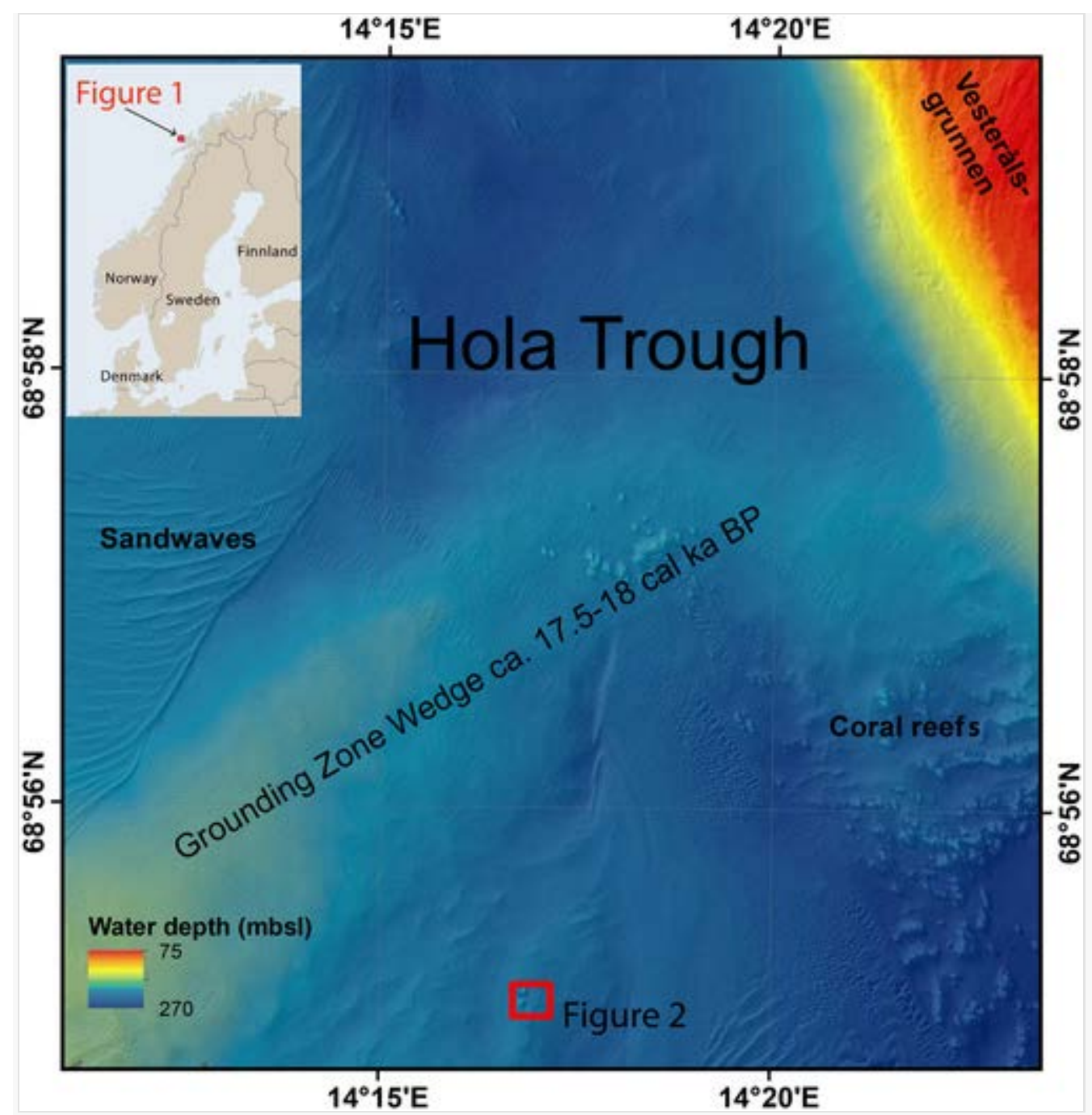

Fig. 1 Multibeam echosounder bathymetry and shaded relief of the Hola trough (from Sauer et al. 2015). The red box outlines the location of Fig. 2a. Morphological features of the Hola trough are sandwaves, cold water coral reefs and a grounding zone wedge crossing the trough. The grounding zone wedge was formed between 17.5 and $18 \mathrm{cal} \mathrm{ka}$ BP due to the deposition of sediments caused by the halt of the retreating ice sheet (Vorren et al. 2015). (For interpretation of the references to colour in this figure legend, the reader is referred to the web version of this article.)

Hydrocarbon sources at this seep site have earlier been assessed using pore water data and headspace gas data (Sauer et al. 2015). We apply mineralogical and petrographical analyses on MDAC crusts and nodules to elucidate carbonate growth, seepage intensity and the environment of carbonate precipitation. Stable carbon $\left(\delta^{13} \mathrm{C}\right)$ and oxygen $\left(\delta^{18} \mathrm{O}\right)$ isotopes on bulk and micro-drilled samples are used to constrain the carbon sources and assess the possible influence of seawater and gas hydrate water in the carbonate precipitation environment. We further use lipid biomarker analyses to investigate AOM-performing microbial consortia involved in the formation of the MDACs. Finally, U-Th geochronology of MDAC crusts from the Hola trough is used to constrain the times of carbonate precipitation and thus, by inference, the past seepage activity.

\section{Oceanographic and geological setting}

The continental shelf offshore the Vesterålen Islands, northern Norway, is relatively narrow and characterized by alternating shallow banks and deeper troughs, which were formed during the last glaciations (Bøe et al. 2009). The study area lies within the Hola trough, which is confined by the Vesterålsgrunnen 
bank to the NE and Eggagrunnen bank to the SW, and contains sandwave fields, cold water coral reefs, and a grounding zone wedge assumed to have formed around 17.5-18 cal ka BP (Vorren et al. 2015) (Fig. 1). The water depth in the Hola trough is ca. $200 \mathrm{~m}$ and bottom water temperature is around $6.5_{-}^{\circ} \mathrm{C}$ (Sauer et al. 2015). The water mass is influenced by the Norwegian Coastal Current and the Norwegian Atlantic Current as well as by bidirectional tidal currents that strongly affect the bottom currents (Bøe et al. 2009).

Basement ridges and large Cretaceous basins which run mainly in a NE-SW direction, and are bounded by a complex extensional fault system, characterize the Lofoten-Vesterålen margin (Blystad et al. 1995; Loeseth and Tveten 1996; Bergh et al. 2007; Færseth 2012). The boundary between basement and sedimentary rocks in this part of the Norwegian shelf coincides with an angular unconformity and has been correlated to regional uplift in Early to early Middle Jurassic times (Løseth 1999). The geological succession offshore Vesterålen comprises Precambrian crystalline basement, Lower Jurassic to Upper Cretaceous sedimentary rocks and a Quaternary sediment cover, which was formed during several glacial cycles (Ottesen et al. 2002; Ottesen et al. 2005). The uppermost sediment layer is a lag deposit created by sediment winnowing due to strong bottom currents (Elvsborg 1979; Bøe et al. 2009; Bellec et al. 2012) and is present in many parts of the shelf. At present, there is no sediment deposition at our study site in the Hola trough (Sauer et al. 2016).

The Fennoscandian Ice Sheet reached the edge of the continental shelf of the Vesterålen-Lofoten margin during the Last Glacial Maximum (LGM) and the deglaciation of the shelf took place in several stages of waxing and waning of the ice sheet (Brendryen et al. 2015). Deglaciation of the Hola trough likely started around $22 \mathrm{cal} \mathrm{ka} \mathrm{BP,} \mathrm{with} \mathrm{the} \mathrm{major} \mathrm{phase} \mathrm{of} \mathrm{deglaciation} \mathrm{of} \mathrm{the} \mathrm{Vesterålen} \mathrm{shelf} \mathrm{between} 19$ and 16 cal ka BP (Vorren et al. 2015).

\section{Materials and methods}

\subsection{Sampling}

During a RV G.O. Sars cruise in August 2014 we used the remotely operated vehicle (ROV) Argus (Argus Remote System AS) for video documentation of the seafloor and for sampling of MDAC crusts (MDAC 2 and 5, Fig. 2) at a cold seep site in the Hola trough at water depths of around $220 \mathrm{~m}$. The locations were chosen based on an autonomous underwater vehicle (AUV) survey of the area in 2013 (Sauer et al. 2015) which identified MDAC crust occurrences (Fig. 2a). Gravity core GC 51 was retrieved in April 2013. The locations of the MDAC samples and gravity core GC 51 are shown and listed in Fig. 2 and Table 1. 


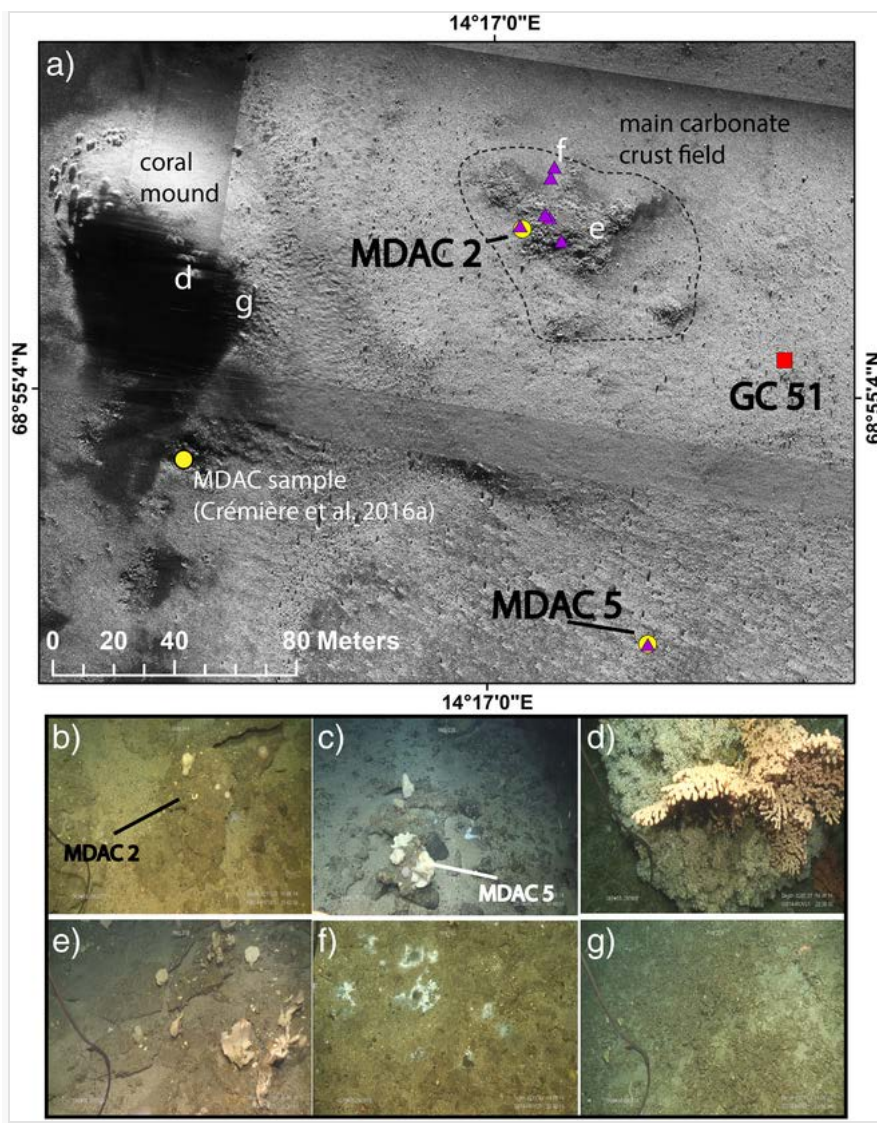

Fig. 2 a) High resolution synthetic aperture sonar (HiSAS) map of the studied area in the Hola trough (Sauer et al. 2015) showing a cold water coral mound, a field of methane-derived authigenic carbonate crusts (outlined by the dashed line), positions of the MDAC samples studied here and by Crémière et al. (2016a)(yellow dots), occurrence of bacterial mats (violet triangles) and location of the gravity core GC 51 (red square, Sauer et al. 2015), b) seafloor image of MDAC 2, c) seafloor image of MDAC 5, d) living cold water coral, e) carbonate crust field and attached macrofauna, f) bacterial mats and g) cold water coral debris. (For interpretation of the references to colour in this figure legend, the reader is referred to the web version of this article.)

Table 1 Coordinates and water depth of MDAC samples and the gravity core GC 51.

\begin{tabular}{|l|l|l|l|}
\hline & \multicolumn{2}{|c|}{ Latitude (N) } & \multicolumn{2}{c|}{ Longitude (E) } & Water depth (m) \\
\hline MDAC 2 & 68.9183 & 14.2836 & ca. 220 \\
\hline MDAC 5 & 68.9170 & 14.2847 & ca. 220 \\
\hline GC 51 & 68.9179 & 14.2858 & 222 \\
\hline
\end{tabular}

In the laboratory, the MDAC crusts were cleaned from loose sediment and large fauna and dried at $40^{\circ} \mathrm{C}$ for $24 \mathrm{~h}$. Subsequently, they were cut vertically into slabs to obtain cross sections which were further subsampled for X-ray diffraction (XRD) analysis, X-ray fluorescence (XRF) analysis, LECO elemental analysis and stable isotope analyses (Fig. 3a and b). The subsamples were crushed using a jaw crusher and subsequently ground and homogenized using an agate mill. 
a)

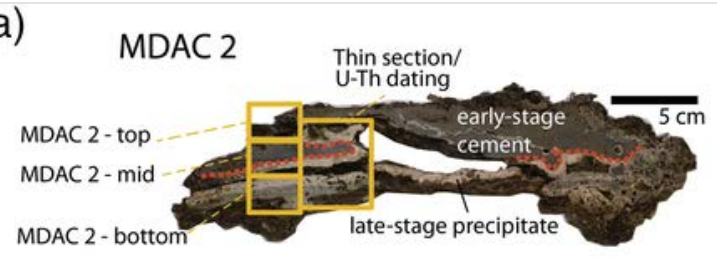

b)
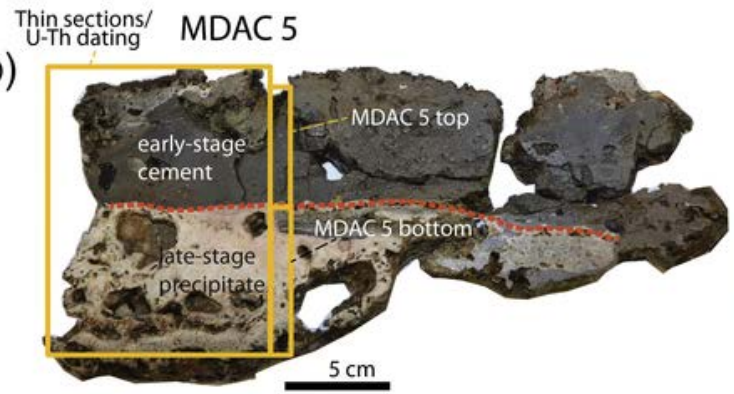

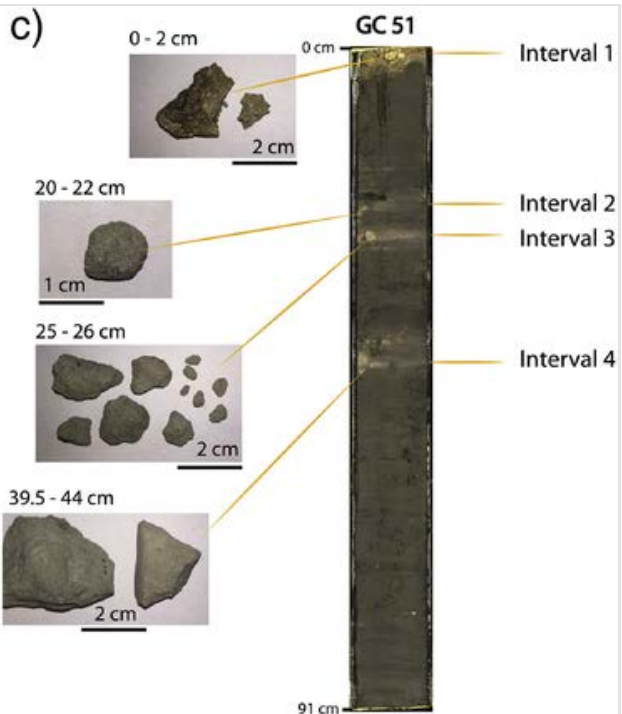

Fig. 3 Photos of slabs cut from MDAC 2 (a) and MDAC 5 (b) with yellow boxes indicating subsamples and how they are referred to in the following. The orange dotted line indicates the boundary between earlystage carbonate-cemented crust and later-stage carbonate precipitate. c) Photos of the upper part of core GC 51 (from Sauer et al. 2016) and the carbonate nodules/crust that were found in four depth intervals. (For interpretation of the references to colour in this figure legend, the reader is referred to the web version of this article.)

The parts of the slabs, with the purest carbonate precipitates (Fig. 3a and b), were fixed with epoxy resin and were used to prepare $4 \times 5 \mathrm{~cm}$ thin sections for petrographic examination (Figs. S1 and S2), as well as for sampling by micro-drilling (U-Th, $\delta^{13} \mathrm{C}, \delta^{18} \mathrm{O}$ ). Additionally, carbonate nodules were collected from four light-coloured intervals identified in core GC 51, which was split into two halves (Fiure). These nodules were washed, dried, and subsampled for further petrographic-mineralogic and chemical analyses. Sediment samples were taken at $5 \mathrm{~cm}$ intervals for lipid biomarker and XRF analyses from core GC 51.

\subsection{Analyses}

\subsubsection{Petrography}

We carried out petrographical characterization of the carbonate samples using an optical microscope with transmitted light. Scanning electron microscope (SEM) analyses were performed on both the MDAC samples from the seabed and the carbonate nodules in GC 51 at the Geological Survey of Norway (NGU) using a Leo 1450 VP with a tungsten emitter, backscatter electron mode and Energy Dispersive Xray Spectroscopy (EDS).

\subsubsection{Mineralogy (XRD)}

Mineralogy was determined by XRD on milled and homogenized bulk powders from the MDAC sample pieces as outlined in Fi g. 3 and four nodules (one from each interval) from GC 51. Prior to analysis, all samples were ground in isopropanol in a McCrone mill. Unoriented specimens of the dried powders were prepared by side-loading. All samples were measured at the NGU on a BRUKER D8 Advance diffractometer

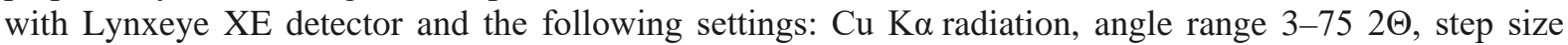
$0.02^{\circ}$ with 1 s per step, primary and secondary soller slits of $2.5^{\circ}$, fixed divergence and fixed $0.6 \mathrm{~mm}$ antiscatter slits. Mineral identification was performed with automatic/manual peak search with BRUKER's Diffrac.EVA 3.1. Both ICDD's PDF4 Mineral database as well as Crystallographic Open Database (COD) were used for identification purposes. Mineral quantification was performed with Rietveld refinement using TOPAS 5. Refined parameters included background coefficients, sample displacement, scale, and unit cell parameters of all phases as well as preferred orientation. Depending on the mineral phase, the lower limit of quantification is commonly $1-2 \mathrm{wt} \%$ and the uncertainty $2-3 \mathrm{wt} \%$. To confirm results from Rietveld refinement, the quantified minerals were re-calculated into element oxide concentrations for comparison with XRF data. 


\subsubsection{Organic and inorganic carbon}

Analyses of total carbon (TC) and organic carbon (TOC) were performed with a LECO SC-632 at the NGU of the same subsamples used for XRD analyses. For TC determination, 300-400 mg of subsample was combusted at $1350{ }^{\circ} \mathrm{C}$ and the production of $\mathrm{CO}_{2}$ determined with an infrared cell. For TOC analysis, 400-450 mg of subsample was placed in carbon-free pervious ceramic combustion boats. These were placed on a heating plate at $50^{\circ} \mathrm{C}\left( \pm 5^{\circ} \mathrm{C}\right)$ and samples treated with 10 vol\% hydrochloric acid ( $\left.\mathrm{HCl}\right)$ to remove inorganic carbon (carbonate) and subsequently rinsed with distilled water and dried in the drying oven prior to analysis in the same way as TC. Results are given in weight percent (wt\%) and the standard deviation of the TC and TOC measurements based on the repeated measurement of a standard was $\pm 0.03 \mathrm{wt} \%$ (abs) $(1 \sigma$, $\mathrm{n}=6)$ and $\pm 0.03 \mathrm{wt} \%$ (abs) $(1 \sigma, \mathrm{n}=11)$, respectively. Calcium carbonate content was calculated as $\mathrm{CaCO}_{3}=(\mathrm{TC}-\mathrm{TOC}) \times 8.33$, and dolomite content as $\mathrm{CaMg}\left(\mathrm{CO}_{3}\right)_{2}=(\mathrm{TC}-\mathrm{TOC}) \times 7.676$.

\subsubsection{Carbon and oxygen isotopes}

Stable carbon and oxygen isotopes were determined on the same subsamples used for XRD and LECO analyses. Furthermore, 20 ca. $100-200 \mu \mathrm{g}$ subsamples for $\delta^{13} \mathrm{C}$ and $\delta^{18} \mathrm{O}$ analyses were micro-drilled with a $2 \mathrm{~mm}$ drill bit from epoxy-fixed slabs (Fig. S1 and S2, Supplementary data).

Stable carbon and oxygen isotopes of hand drilled carbonate and homogenized bulk sample pieces were analysed with a GasBench II preparation line connected to a Delta V Advantage IRMS (Thermo Fisher Scientific) at Tallinn University of Technology in Estonia. Stable isotope compositions are reported in conventional delta $(\delta$ ) units relative to the Vienna Pee Dee Belemnite (VPDB) reference. Reproducibility is better than $\pm 0.2 \%$ for both $\delta^{13} \mathrm{C}$ and $\delta^{18} \mathrm{O}$.

All $\delta^{18} \mathrm{O}$ values were calculated using the acid fractionation factor for aragonite (Kim et al. 2007a) since most samples consisted dominantly of aragonite. There is thus some uncertainty regarding the dolomite $\delta^{18} \mathrm{O}$ values because the dolomite-acid fractionation factor could be slightly different. We still used the aragonite-acid fractionation factor due to only basic estimates of the dolomite-acid fractionation factor (Rosenbaum and Sheppard 1986).

To calculate the $\delta^{18} \mathrm{O}$ of the fluid from which the aragonite samples precipitated we used the fractionation factor-.14 and the equation $\delta^{18} \mathrm{O}_{\text {wate }}(\mathrm{SMOW})=\delta^{18} \mathrm{O}_{\text {arag }}(\mathrm{PDB})-\left(19.7-\mathrm{t}\left({ }^{\circ} \mathrm{C}\right)\right) / 4.34$ (SMOW - Standard Mean Ocean Water) (Grossman and Ku 1986). For the dolomite nodules, we used the fractionation factor-temperature relationship from Vasconcelos et al. (2005): $1000 \ln \alpha$ dolomitewater $=2.73 *\left(10^{6} / \mathrm{T}(\text { Kelvin })^{2}\right)+0.26$.

\subsubsection{U-Th geochronology}

Ten subsamples were micro-drilled from MDAC 2 and eight subsamples from MDAC 5 in selected locations of late-stage pure aragonite for U-Th dating. Sample weight was between 3.7 and $10.5 \mathrm{mg}$ (Table S1, Supplementary material). U and Th chemical separation and mass spectrometry (Thermo Neptune multicollector ICP-MS) were carried out at the NERC Isotope Geosciences Laboratory (NIGL), British Geological Survey, Keyworth, following the analytical protocols outlined by Crémière et al. (2016a, 2016b). $\mathrm{U}$-Th age calculations were performed using an in-house Excel spreadsheet using the ${ }^{230} \mathrm{Th}$ and ${ }^{234} \mathrm{U}$ decay constants of Cheng et al. (2013), and a detrital correction based on average measured $\left({ }^{232} \mathrm{Th} /{ }^{238} \mathrm{U}\right),\left({ }^{230} \mathrm{Th} /{ }^{238} \mathrm{U}\right)$, and $\left({ }^{234} \mathrm{U} /{ }^{238} \mathrm{U}\right)$ activity ratios of carbonate-free detritus samples (detrital correction option 3 from Crémière et al. 2016a) and ages are reported as ka before present (BP = before 1950).

\subsubsection{Inorganic sediment geochemistry \\ 3.2.6.1 XRF core scan}

XRF core logging was carried out with a DELTA Handheld XRF sensor on a Standard MSCL (MSCL-S) core logger (GeoTek Ltd., UK). The XRF sensor is equipped with a $4 \mathrm{~W}$ Rh-tube anode and Si Drift detector. Prior to core measurements the XRF sensor was standardized and SRM 2710a Montana soil I standard (Mackey et al. 2010) was stationary measured for sensor-control purposes. To prevent contamination of the XRF sensor during scanning the soft, wet sediment was covered with $4 \mu \mathrm{m}$ thick Ultralene ${ }^{\circledR}$ window film. Down core XRF measurements were taken incrementally along the longest axis in the centre of the split core surface with $0.5 \mathrm{~cm}$ steps. Two measurements in succession with $40 \mathrm{keV}$ and $10 \mathrm{keV}$ currents a nd $10 \mathrm{~s}$ exposure time each provided spectra covering chemical elements from $\mathrm{Mg}$ to $\mathrm{Pb}$, of which only the ratio of $\mathrm{Ca}$ and $\mathrm{Ti}$ was used in this study. 


\subsubsection{XRF}

Sediment samples taken for XRF analysis were milled, homogenized_and subsequently analysed at the NGU with a PANalytical Axios sequential wavelength-dispersive X-ray spectrometer operating with a $4 \mathrm{~kW}$ Rh-tube. For major element analysis, the sample material was fused to glass beads with $\mathrm{Li}_{2} \mathrm{~B}_{4} \mathrm{O}_{7}$ at $1200{ }^{\circ} \mathrm{C}$ at NGU. Loss on ignition was determined after two hours at $100{ }^{\circ} \mathrm{C}$. The major elements generally have a lower limit of detection of $0.01 \mathrm{wt} \%$. The analytical uncertainty is concentration-dependent, but usually better than $5 \%$ rel. $(2 \sigma)$.

\subsubsection{Organic geochemistry}

The isotopic composition of the organic material $\left(\delta^{13} \mathrm{C}-\mathrm{TOC}\right)$ in the carbonate crust was analysed on the bulk decarbonated $(15 \% \mathrm{HCl})$ sample on an Isoprime mass spectrometer connected to an elemental analyser (Carlo Erba 2500). Triplicates of each sample were performed. The uncertainty was up to $\pm 0.3 \%$ and values are reported against the international standard Vienna Pee Dee Belemnite (VPDB).

For the analyses of neutrals and fatty acids (FA) ca. $10 \mathrm{~g}$ of decarbonated and freeze-dried crust (or sediment sample) were extracted using dichloromethane/methanol (7:3 volume) in a microwave. By running the extract over a sodium sulphate column and a $\mathrm{Cu}$ column, traces of water and sulphur were removed, respectively. After saponifying the extract with $6 \% \mathrm{KOH}$ in $\mathrm{MeOH}$ for $3 \mathrm{~h}$ at $80{ }^{\circ} \mathrm{C}$, the neutral fraction was extracted with hexane and the acid fraction was extracted with hexane from the aqueous phase after the addition of $\mathrm{HCl}(\mathrm{pH}$ below 2). Traces of water were again removed using a sodium sulphate column. Subsequently, neutrals were derivatised with BSTFA (Sigma) and FAs were methylated with 10\% $\mathrm{BF}_{3} / \mathrm{MeOH}$ (Sigma) for $2 \mathrm{~h}$ at $100{ }^{\circ} \mathrm{C}$ to produce methyl esters (FAMEs). Concentrations of neutrals and fatty acids were examined using GC-FID (Shimadzu GC-2010 Plus with an Inert Caps 5MS/NP column). Identification of the individual FAs (iso- and anteisoi- $\mathrm{C}_{15: 0}$ ) was done by comparison of retention times by commercially available standards (BAME and FAME, Supelco) and by gas chromatography-mass spectrometry (GC-MS, Shimadzu GCMS-QP 2010 Ultra equipped with a Phenomenex Zebron phase ZB5MSi column). Archaeol and sn-2-hydroxyarchaeol were identified by mass spectrometry using published mass spectra. Gas chromatography coupled with isotope ratio-mass spectrometry (GC-IRMS, Thermo with Restek RXi 5 ms column) was used to analyse compound specific $\delta^{13} \mathrm{C}$ values [\%o Vienna Pee Dee Belemnite (VPDB)]. The analytical uncertainty was below 2\%o (C4 n-alkane standard, Schimmelmann).

\section{Results}

\subsection{Seafloor visual observations}

MDAC crusts were found on the seafloor in close association w ith coral mounds (Fig. 2a). The crusts are up to several tens of centimetres thick and occur in one main carbonate crust field, which covers an area of ca. $2000 \mathrm{~m}^{2}$ and several smaller patches in the vicinity (Fig. 2). The MDAC crusts provide a habitat for abundant living macrofauna, some of which are attached to the crusts (Fig. 2e). The seafloor around the carbonate crust area is characterized by a lag deposit, which is ca. $10 \mathrm{~cm}$ thick and dominated by coarse sediments up to boulder size (Fig. 2b-g). Close to the sampling sites of MDAC 2 and 5 we observed whitish bacterial mats at the sediments surface (Fig. 2b and c) and gas bubbling during sampling indicating gas saturated sediment.

\subsection{Petrography of MDAC crusts and nodules}

MDAC 2 was ca. $60 \mathrm{~cm}$ long, $30 \mathrm{~cm}$ wide and $8 \mathrm{~cm}$ thick, whereas MDAC 5 was ca. $40 \mathrm{~cm}$ in diameter and $15 \mathrm{~cm}$ thick (Fig. 2b and c). Both MDAC 2 and 5 consist of carbonate-cemented sediments and pure carbonate (Fig. 3a and b). The carbonate cement represents the earliest stage of carbonate precipitation, whereas the pure carbonate represents later-stage carbonate precipitation filling cavities (e.g. Crémière et al. 2016a). In core GC 51, the upper $91 \mathrm{~cm}$ contain 4 light-coloured intervals reflecting the presence of finely dispersed authigenic carbonate $(0-2 \mathrm{~cm}, 20-22 \mathrm{~cm}, 25-26$ and $39-44.5 \mathrm{~cm})$ with abundant carbonate nodules (Fig. 3c). The sedimentology of GC 51 has been described in more detail by Sauer et al. (2016). The nodules are variably cemented, ranging from rather poorly cemented nodules (between 20 and $26 \mathrm{~cm}$ ) to well-cemented larger nodules $(39.5-44 \mathrm{~cm})$. The nodules from the three lowermost intervals $(2-4)$ are similar in terms of shape and incorporate mostly silt-sized silicate detritus, whereas the carbonate piece in the topmost interval (1) of GC 51 is more angular and contains coarser grained, sand-sized sediments, visually similar to MDAC 2 and 5 . 
Two carbonate phases were identified in the MDAC crust samples: aragonite accounting for up to $98 \mathrm{wt} \%$ of all carbonate, and calcite. The carbonate piece from interval 1 in core GC 51 shows the same carbonate mineralogy as the MDAC crust samples with dominantly aragonite and some calcite. Conversely, the carbonate mineralogy of the nodules from intervals 2 to 4 is dominated by dolomite, with minor amounts of Mg-calcite (Table 2).

Table 2 Concentration of organic and inorganic carbon (recalculated to $\mathrm{CaCO}_{3}$ and $\left.\mathrm{CaMg}\left(\mathrm{CO}_{3}\right)_{2}\right)$ and mineral composition of MDAC 2 and 5, and carbonate nodules from core GC 51. For almost all samples, the carbonate content determined by XRD analyses was slightly higher compared to carbonate content determined by the LECO elemental analyser. The reason for this discrepancy could be that for XRD mineral quantification the sum of the identified minerals is assumed to be $100 \%$, and hence minor mineral phases are not counted, which is increasing the relative proportion of the major minerals. Another reason could be that LECO values for inorganic carbon are too low, or that the samples were not thoroughly enough homogenized before splitting for the different analyses.

\begin{tabular}{|c|c|c|c|c|c|c|c|c|c|c|c|c|c|}
\hline & \multicolumn{3}{|c|}{ Leco (in wt\%) } & \multicolumn{10}{|c|}{ XRD (in wt\%) } \\
\hline & TOC & $\mathrm{CaCO}_{3}$ & $\mathrm{CaMg}\left(\mathrm{CO}_{3}\right)_{2}$ & Quartz & $\begin{array}{c}\text { K- } \\
\text { feldspar }\end{array}$ & $\begin{array}{l}\text { Plagio- } \\
\text { clase }\end{array}$ & Aragonite & Calcite & (Mg)calcite & Dolomite & Illite/Muscovite & Amphibole & Chlorite \\
\hline $\begin{array}{l}\text { MDAC } \\
2 \text { - top }\end{array}$ & 0.2 & 41 & & 16 & 8 & 19 & 49 & 4 & & Traces? & 2 & 2 & \\
\hline $\begin{array}{l}\text { MDAC } \\
2 \text { - mid }\end{array}$ & 0.6 & 61 & & 10 & 4 & 11 & 72 & 3 & & & $<1$ & & \\
\hline $\begin{array}{l}\text { MDAC } \\
2 \text { - } \\
\text { bottom }\end{array}$ & 0.3 & 73 & & 6 & 3 & 8 & 74 & 9 & & & & Traces & \\
\hline $\begin{array}{l}\text { MDAC } \\
5 \text { - top }\end{array}$ & 0.4 & 51 & & 10 & 7 & 18 & 63 & 2 & & & Traces & & \\
\hline $\begin{array}{l}\mathrm{MDAC} \\
5- \\
\text { bottom }\end{array}$ & 0.5 & 93 & & $<1$ & & $<1$ & 97 & 2 & & & & & \\
\hline $\begin{array}{l}\text { Interval } \\
1\end{array}$ & 0.2 & 44 & & 17 & 10 & 21 & 36 & 6 & & & 4 & 4 & 2 \\
\hline $\begin{array}{l}\text { Interval } \\
2\end{array}$ & 0.3 & & 39 & 17 & 10 & 19 & & & 2 & 42 & 2 & 6 & 2 \\
\hline $\begin{array}{l}\text { Interval } \\
3\end{array}$ & 0.3 & & 37 & 18 & 10 & 20 & & & 2 & 38 & 3 & 6 & 3 \\
\hline $\begin{array}{l}\text { Interval } \\
4\end{array}$ & 0.3 & & 44 & 15 & 8 & 17 & & & 3 & 46 & 3 & 5 & 3 \\
\hline
\end{tabular}

The $\mathrm{CaCO}_{3}$ content of bulk samples from MDAC 2 and MDAC 5 determined by LECO analysis ranged from 41 to $73 \mathrm{wt} \%$ and from 51 to $93 \mathrm{wt} \%$, respectively (Table 2). The $\mathrm{CaCO}_{3}$ content of the carbonate piece of interval 1 was $44 \mathrm{wt} \%$. Carbonate in nodules of interval 2-4 was converted to dolomite content (39-44 wt \%), since this was the dominant carbonate phase determined via XRD analyses (Table 2).

The average TOC content for the MDAC crust samples and the nodules is $0.4 \mathrm{wt} \% \pm 0.2$ and $0.3 \mathrm{wt} \% \pm 0.1$, respectively. These values are similar to sedimentary TOC values of the upper $1 \mathrm{~m}$ of core GC 51 which range between 0.2 and 0.7 wt\% (Sauer et al. 2016).

Optical microscopy and SEM images of MDAC 2 (Fig. 4a) confirm that aragonite occurs either as microcrystalline cement between (1) detrital grains of mostly quartz and feldspar in the sand size fraction (Fig. 4a-2), (2) between detrital grains mixed with bioclasts such as foraminifera tests and echinoderm skeletal fragments (Fig. 4a-3), or (3) as pure aragonite phase lining the cavities (Fig. 4a-4 and -5). 


\section{a) MDAC 2}

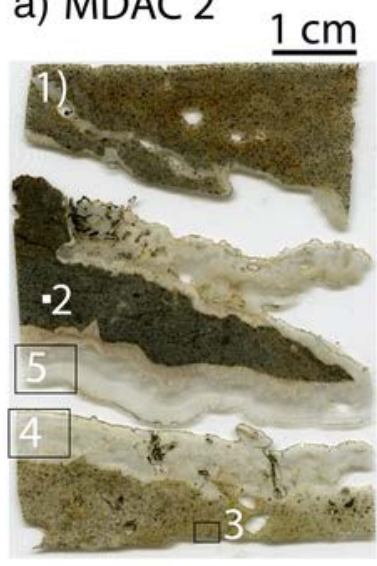

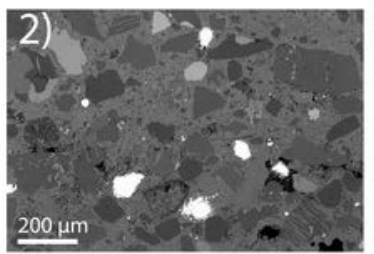
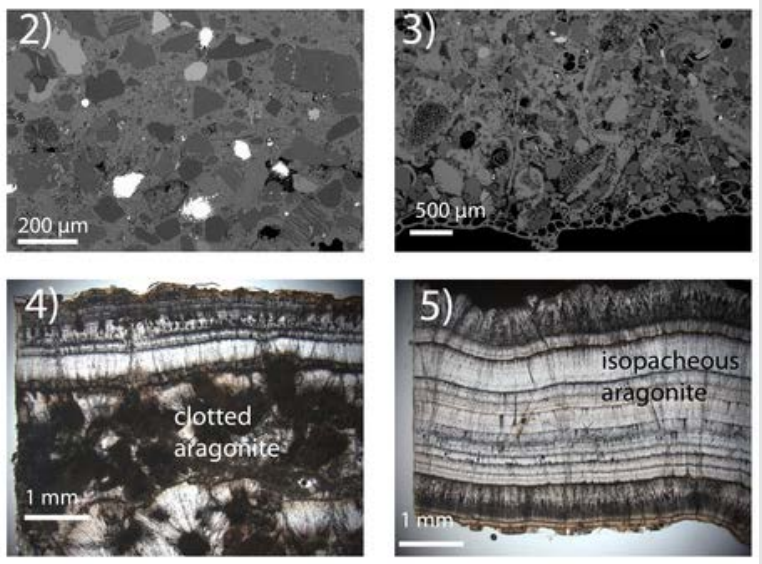

b) MDAC 5-B

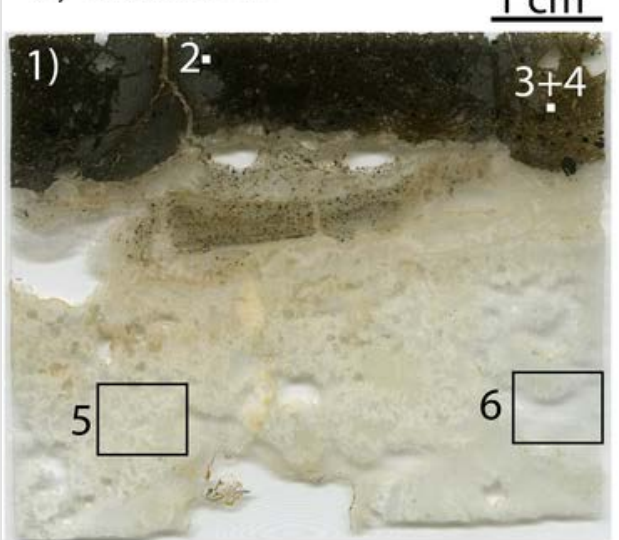

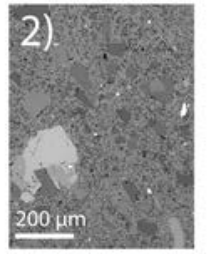
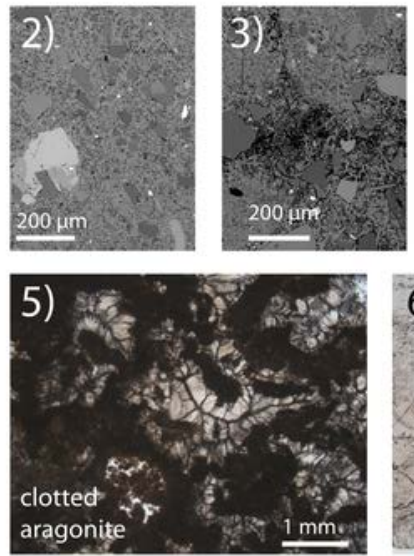
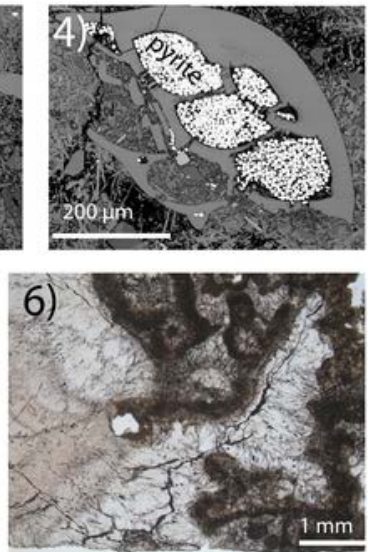

Fig. 4 a) (1) Thin section image of MDAC 2 indicating the location of the SEM images and photomicrographs; (2) SEM backscatter electron image showing microcrystalline aragonite cement, quartz and feldspar grains which form the majority of the detrital grains, and white grains which are Fe-Ti oxides; (3) a more weakly cementing aragonite matrix with more bioclasts; (4) optical microscope photomicrograph of clotted aragonite (lower part of image) and lucent botryoidal aragonite; (5) botryoidal aragonite forming isopacheous layers between 100 and $500 \mu \mathrm{m}$ thickness. b) (1) Thin section image of MDAC 5 (location outlined in Fig. S2 in the Supplementary material); (2) SEM backscatter electron image showing microcrystalline aragonite cementing quartz and feldspar grains tightly and (3) loosely. (4) SEM backscatter electron image of framboidal pyrite precipitation within a foraminifera shell. (5) Optical microscope photomicrograph of mostly clotted aragonite and (6) mostly lucent aragonite.

The pure aragonite phase can be divided into whitish to slightly yellowish clotted aragonite and lucent botryoidal aragonite. The clotted aragonite consists of aragonite crystal aggregates (or microclots) and is dark brown in transmitted light (Fig. 4a-4), probably due to organic remains within the carbonate. These microclots are the nucleation point of aragonite needles growing radially around them (a fabric typically observed in microbialites) (Fig. 4a-4) and then turning into isopacheous, $100-500 \mu \mathrm{m}$ thick layers as the very last stage of carbonate precipitation (Fig. 4a-5). In MDAC 2 botryoidal aragonite is volumetrically more abundant than clotted aragonite.

MDAC 5 shows a fibrous aragonite matrix cementing detrital sand-sized grains, with areas of denser cement (Fig. 4b-2) and areas of less dense cement (Fig. 4b-3). The pure carbonate phase is dominated by clotted aragonite (Fig. 4b-5).

The carbonate crust from interval 1 in core GC 51 is cemented by microcrystalline aragonite (mostly aragonite needles), whereas the carbonate cement of intervals 2-4 is composed of microcrystalline dolomite (Fig. 5). Furthermore, we identified authigenic barite crystals and crystal aggregates in all the intervals (e.g. Fig. 5c), as well as pyrite and other iron sulphides. Authigenic barite crystals occur predominantly in interval 3 (Fig. 6). 

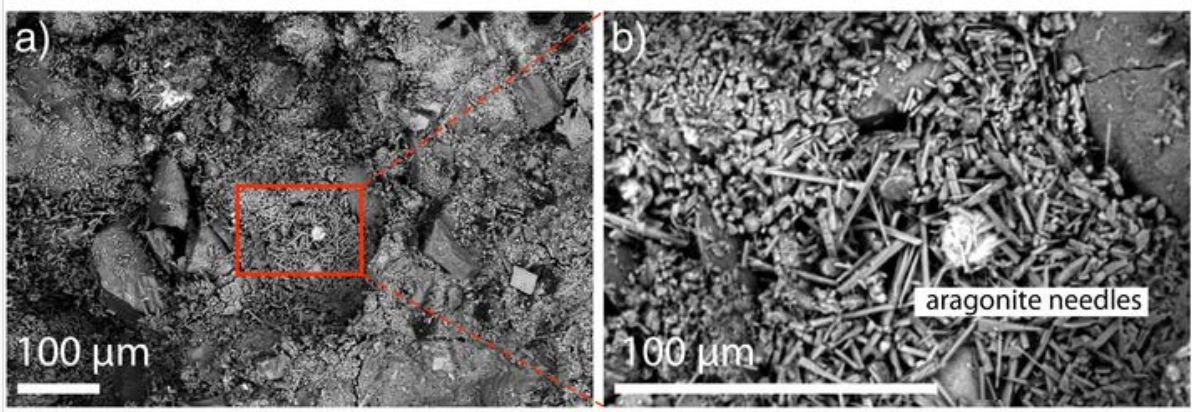

Interval-2

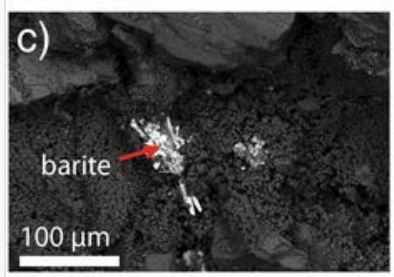

Interval-3

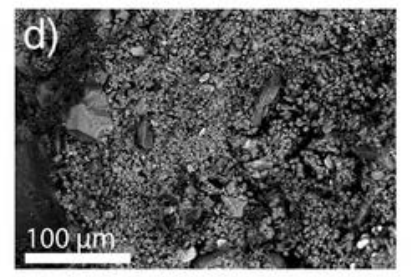

r
Interval-4

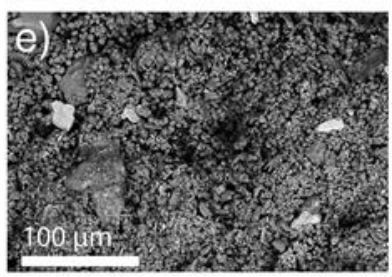

microcrystalline dolomite cement

Fig. 5 SEM backscatter electron images of carbonate crust/nodules from core GC 51. (a,b): Interval 1-crust contains microcrystalline aragonite cement. (c,d,e): The nodules from Fig. 5 cemented by microcrystalline dolomite. Barite crystals and crystal aggregates were observed in several nodules (e.g. image c).

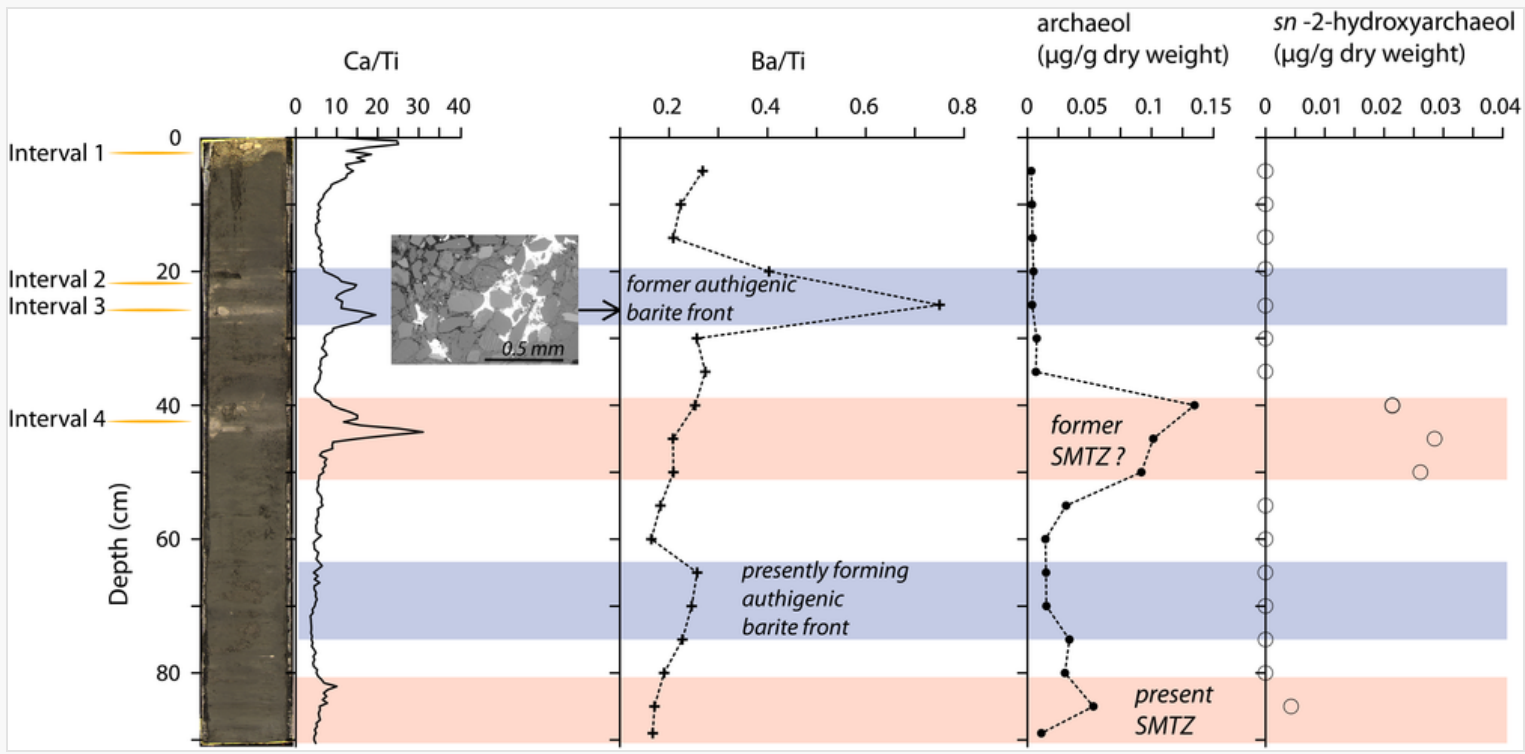

Fig. 6 Elemental and organic geochemical characteristics of the upper $91 \mathrm{~cm}$ of core GC 51. From left to right: colour photo of the core, $\mathrm{Ca} / \mathrm{Ti}$ ratio determined by XRF scanning, $\mathrm{Ba} / \mathrm{Ti}$ ratio determined on discrete sediment samples by XRF analysis, archaeol and sn-2-hydroxyarchaeol concentration in the sediment. The inset shows a SEM image of a dolomite nodule from interval 3 containing large amounts of authigenic barite (white). The two light red bands indicate the location of the present and suggested past sulphate-methane-transition zone. The blue bands represent intervals of Ba enrichment in the sediment. (For interpretation of the references to colour in this figure legend, the reader is referred to the web version of this article.)

\subsection{Element ratios in the sediment}


The Ca/Ti ratio varies between 3.5 and 31 in the upper $91 \mathrm{~cm}$ of core GC 51 (Fig. 6). The highest values are found in the following intervals: $0-5 \mathrm{~cm}$ (up to 25), 20-23 cm (up to 15), 24-27 cm (up to 19.5), $39-44.5 \mathrm{~cm}$ (up to 31 ) and $80--85 \mathrm{~cm}$ (up to 10). Furthermore, the Ba/Ti ratio of discrete samples varied between 0.16 and 0.75 and showed two intervals with higher values: $20-30 \mathrm{~cm}$ and $65-75 \mathrm{~cm}$ (Fig. 6, Table S2 Supplementary material). A detailed description of the sedimentology of core GC 51 can be found in Sauer et al. (2016).

\subsection{Carbon and oxygen stable isotopes of carbonate}

We obtained carbon and oxygen stable isotope data of carbonate from homogenized bulk subsamples of crust (5 samples, Fig. 3) and from micro-drilled powder from locations close to spots where samples for U-Th dating were micro-drilled (20 samples, Fig. S1 and S2, Supplementary material). The isotope data of whole rock and micro-drilled samples show $\delta^{13} \mathrm{C}$ values ranging between $-22.2 \%$ and $-34.6 \%$ with an average of $-29.7 \%$ (VPDB) for MDAC 2, and between $-25.3 \%$ and $-33.5 \%$ with an average of $-29.4 \%$ (VPDB) for MDAC 5 (Fig. 7a). The $\delta^{13} \mathrm{C}$ values of the carbonate nodules/crust from core GC 51 are less negative and range between $-9.2 \%$ and $-12.5 \%$ (Fig. 7b, Table S3, Supplementary material). For MDAC 2 and 5 the $\delta^{18} \mathrm{O}$ values of both bulk subsamples and micro-drilled samples range between 2.5\%oand 3.4\% (average 3.0\% (VPDB)) and between 2.0\% and 3.7\% (average 3.1\%o (VPDB)), respectively (Fig. 7b, Table S3). The $\delta^{18} \mathrm{O}$ values of the nodules/crust from GC 51 are notably higher and vary between 3.7\% and 5.3\%.

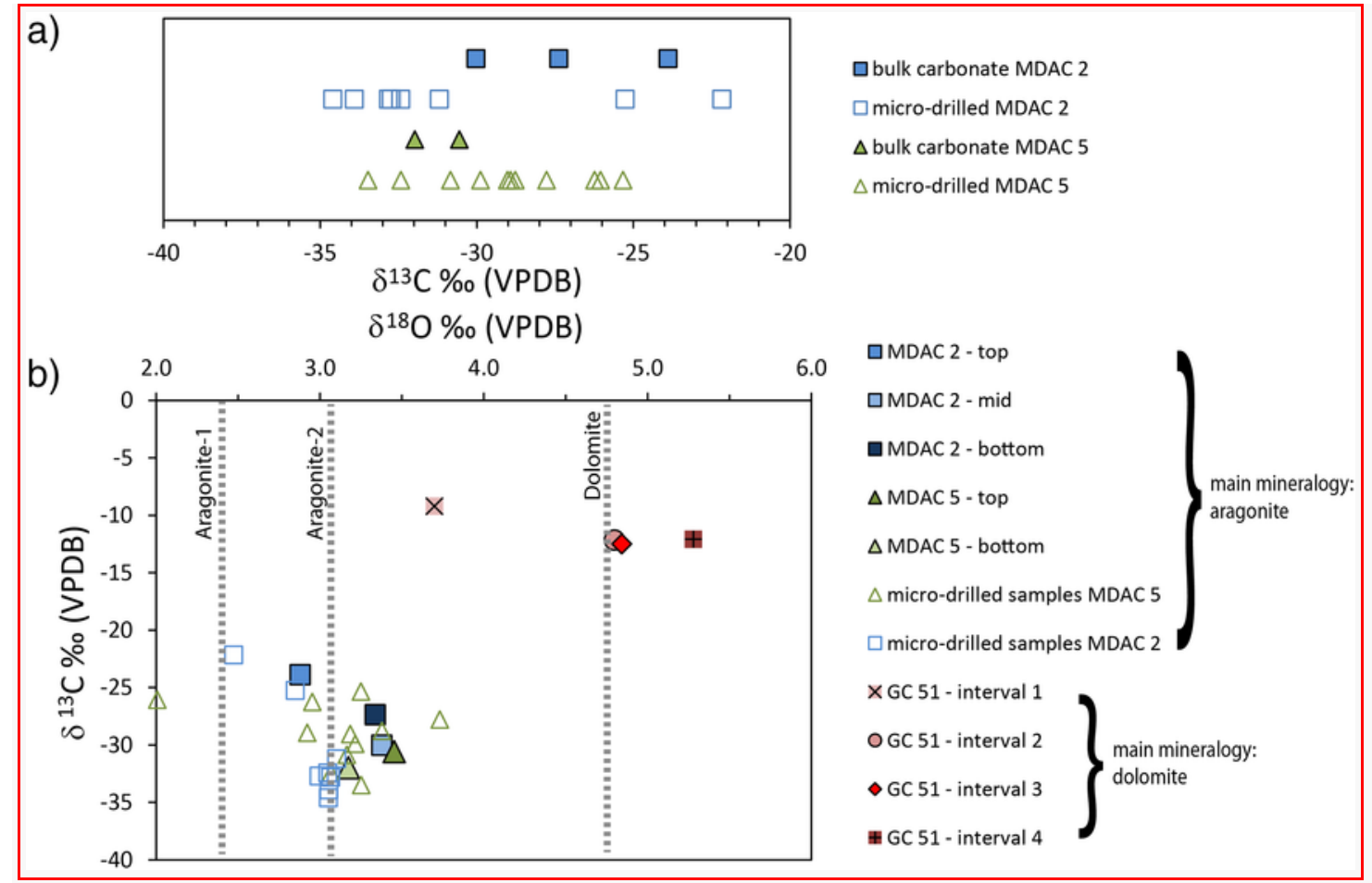

Fig. 7 a) Comparison between $\delta^{13} \mathrm{C}$ results of bulk and micro-drilled samples of MDAC 2 and MDAC 5. b) Plot of stable carbon and oxygen isotope composition of the MDAC samples and the carbonate nodules from core GC 51 . The difference in $\delta^{18} \mathrm{O}$ (VPDB) can be mostly accounted for by the difference in carbonate mineralogy. The dashed lines represent the $\delta^{18} \mathrm{O}$ values of aragonite-1 (Kim et al., 2007b) aragonite-2 (Grossman and Ku 1986) and dolomite (Vasconcelos et al. 2005) in equilibrium with present bottom water $\left(T=6.5^{\circ} \mathrm{C}, \delta^{18} \mathrm{O}_{\text {seawater }}=0 \%\right)$.

\subsection{Organic geochemistry}

We analysed two samples (MDAC 2 and MDAC 5) for their concentrations of archaeal lipids, archaeol (Ar) and sn-2- hydroxyarchaeol $(\mathrm{OH}-\mathrm{Ar})$, and of bacterial lipids, iso $C_{15: 0}\left(\mathrm{i}-\mathrm{C}_{15: 0}\right)$ and anteiso$C_{15: 0}$ (ai-C $\left.C_{15: 0}\right)$ fatty acids, and their compound specific $\delta^{13} C$ signatures as well as the $\delta^{13} C$ of bulk organic matter (Table 3). In MDAC 2 and MDAC 5 the concentration of archaeol was 2.11 and $7.3 \mu \mathrm{g} / \mathrm{g}$ dry weight, 
respectively, and the concentration of sn-2-hydroxyarchaeol was 3.55 and $12.72 \mu \mathrm{g} / \mathrm{g}$ dry weight, respectively. The compound-specific isotopic signature was - 108\% (Ar) and - 104\%o (OH-Ar) in MDAC 2 and - 107\% (Ar) and - 103\% (OH-Ar) in MDAC 5.

Table 3 Concentrations and compound-specific $\delta^{13} \mathrm{C}$ values of selected alcohols and fatty acids (and total organic carbon, TOC) extracted from MDAC 2 and MDAC 5.

\begin{tabular}{|c|c|c|c|c|}
\hline & & & MDAC 2 & MDAC 5 \\
\hline & TOC & $\delta^{13} \mathrm{C}(\%$ V-PDB) & -54.2 & -60.5 \\
\hline \multirow[t]{5}{*}{ Alcohols } & \multirow[t]{2}{*}{ Archaeol } & ( $\mu \mathrm{g} / \mathrm{g}$ dry weight) & 2.1 & 7.3 \\
\hline & & $\delta^{13} \mathrm{C}(\%$ V-PDB $)$ & -107.6 & -106.9 \\
\hline & \multirow[t]{2}{*}{ sn-2-hydroxyarchaeol } & ( $\mu \mathrm{g} / \mathrm{g}$ dry weight) & 3.6 & 12.7 \\
\hline & & $\delta^{13} \mathrm{C}(\%$ V-PDB $)$ & -104.1 & -103.0 \\
\hline & $\mathrm{OH}-\mathrm{Ar} / \mathrm{Ar}$ & & 1.7 & 1.7 \\
\hline \multirow[t]{5}{*}{ Fatty acids } & \multirow[t]{2}{*}{ Iso - C15:0 } & ( $\mu \mathrm{g} / \mathrm{g}$ dry weight) & 1.8 & 6.0 \\
\hline & & $\delta^{13} \mathrm{C}$ (\% V-PDB) & -62.4 & -91.2 \\
\hline & \multirow[t]{2}{*}{ Anteiso - C15:0 } & ( $\mu \mathrm{g} / \mathrm{g}$ dry weight) & 1.6 & 4.4 \\
\hline & & $\delta^{13} \mathrm{C}(\%$ V-PDB) & -63.3 & -88.2 \\
\hline & Anteiso/iso & & 0.9 & 0.7 \\
\hline
\end{tabular}

The concentration of bacterial lipids was $1.84 \mu \mathrm{g} / \mathrm{g}$ dry weight $\left(i-\mathrm{C}_{15: 0}\right)$ and $1.64 \mu \mathrm{g} / \mathrm{g}$ dry weight ( $\mathrm{ai}$ $\left.\mathrm{C}_{15: 0}\right)$ in MDAC 2 and $5.99 \mu \mathrm{g} / \mathrm{g}$ dry weight $\left(i-\mathrm{C}_{15: 0}\right)$ and $4.41 \mu \mathrm{g} / \mathrm{g}$ dry weight $\left(a i-\mathrm{C}_{15: 0}\right)$ in MDAC 5 (Table 3). Compound-specific $\delta^{13} \mathrm{C}$ values of the bacterial lipids were less negative than the measured archaeal lipids and showed a greater variation between the 2 samples. MDAC 2 showed the highest $\delta^{13} \mathrm{C}$ values of fatty acids with $-62 \%\left(i-C_{15: 0}\right)$ and $-63 \%$ o $\left(a i-C_{15: 0}\right)$. In MDAC 5 the values were $-91 \%$ o $\left(i-C_{15: 0}\right)$ and $-88 \%$ o (ai-C15:0).

In the sediment samples of the upper $91 \mathrm{~cm}$ of core GC 51 the concentrations of $\mathrm{Ar}$ and $\mathrm{OH}-\mathrm{Ar}$ varied between 0.003 and $0.135 \mu \mathrm{g} / \mathrm{g}$ dry weight and $0.004-0.029 \mu \mathrm{g} / \mathrm{g}$ dry weight, respectively (Fig. 6, Table S2 Supplementary material). Ar concentrations were highest in the interval $40-50 \mathrm{~cm}$ and at $85 \mathrm{~cm}$ coinciding with the depths where $\mathrm{OH}-\mathrm{Ar}$ was detected. The $\delta^{13} \mathrm{C}$ of bulk organic carbon was $-54.2 \%$ in MDAC 2 and $-60.5 \%$ in MDAC 5 based on three duplicate measurements. In the analysed core interval the $\delta^{13} \mathrm{C}$ values of sedimentary organic carbon varied between $-26.2 \%$ and $-24.6 \%$ (Sauer et al. 2016).

\subsection{U-Th geochronology}

Eighteen samples from two MDAC crusts were dated using U-Th geochronology. All samples are from later stage cavity infills of pure aragonite with as little as possible detrital components. However, two samples from MDAC 2 were excluded from the interpretation due to high Th contribution from detrital material. The remaining samples showed $U$ concentrations of $1.7-6.8 \mathrm{ppm}$ and ${ }^{232} \mathrm{Th}$ concentrations of $1-$ $257 \mathrm{ppb}$ (Table S1, Supplementary material). ${ }^{230} \mathrm{Th} /{ }^{232} \mathrm{Th}$ activity ratios varied between 2.4 and 211 (Table S1). Calculated initial $\delta^{234} \mathrm{U}$ values ranged between 145.9 and 164.8 (Fig. S3), slightly above average seawater composition of $146.6 \pm 2.5 \%$ o (Robinson et al. 2004).

The obtained ages from MDAC 2 range between $1.61 \pm 0.02$ and $4.39 \pm 1.63 \mathrm{ka}$ BP and from MDAC 5 between $2.65 \pm 0.02$ and $4.32 \pm 0.08$ ka BP (Fig. 8a and b). All relevant isotopic data for the U-Th 
dating are summarised in Table S1 in the Supplementary material. The estimated carbonate growth rate within one cavity in the MDAC 2 sample, which shows distinct layers of lucent isopacheous aragonite (Fig. 4a-5) and a clear uniform growth direction (dates 3 and 4 in Fig. 8a) isaround $5.3 \mathrm{~mm} / \mathrm{ka}$.

a)
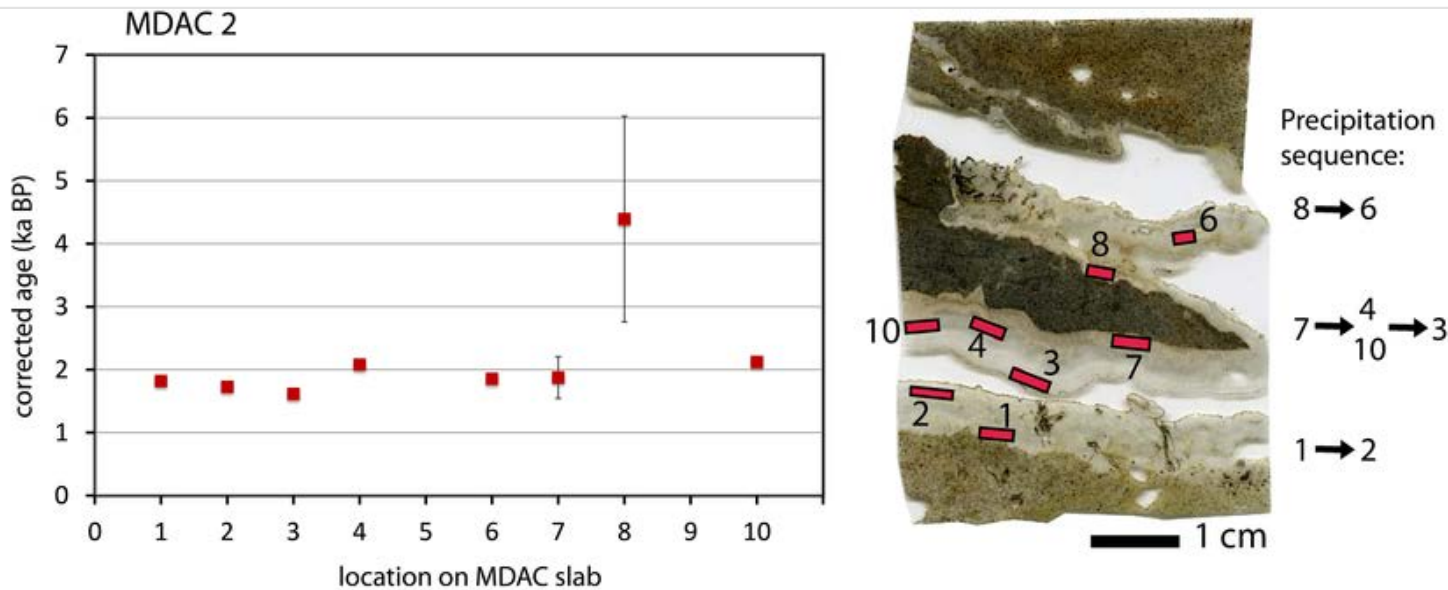

b)
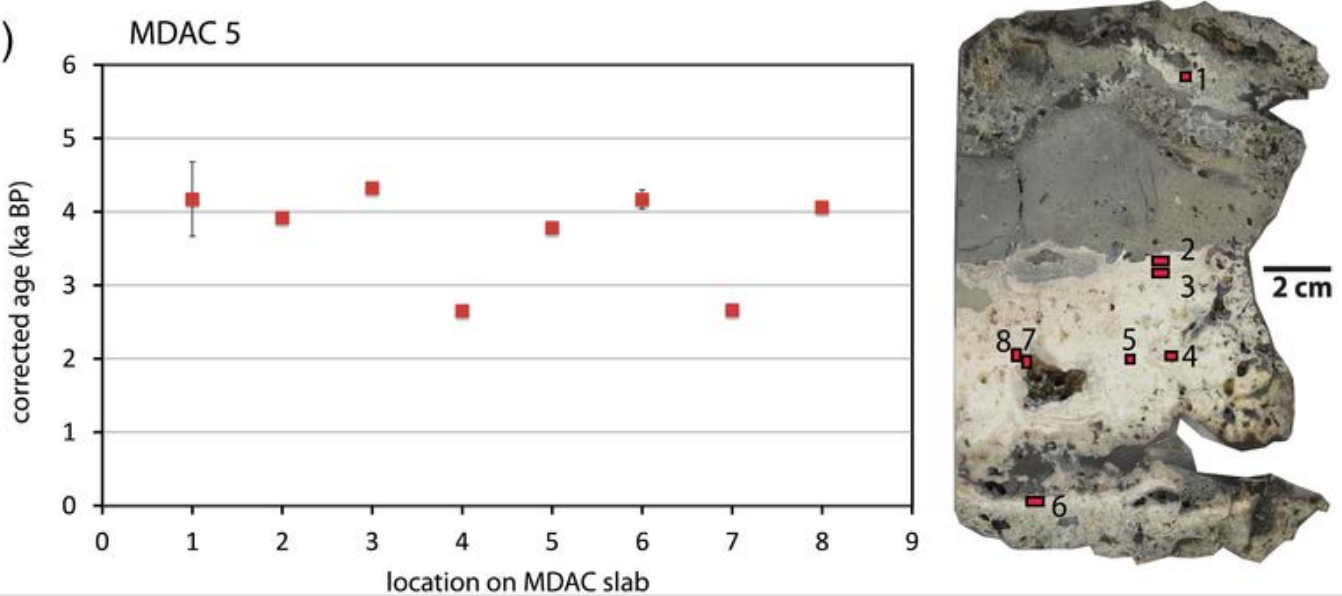

Fig. 8 Plots of U-Th dating results (left) of MDAC 2 (a) and MDAC 5 (b) and photos of the crust pieces with locations of sample spots (right).

\section{Discussion}

\subsection{Formation environment of methane-derived authigenic carbonates}

\subsubsection{Mineralogy}

A variety of carbonate minerals have been found in cold seep carbonates including aragonite, calcite, low-Mg calcite (LMC), high-Mg calcite (HMC), protodolomite, dolomite, ankerite and siderite (e.g. Lu et al. 2015, and references therein). Several factors have been found to influence the Mg-Cacarbonate mineralogy such as the degree of supersaturation, the concentration of $\mathrm{Mg}^{2+}$ and $\mathrm{Ca}^{2+}$ in pore water/seawater, sulphate and phosphate concentration, temperature, partial pressure of $\mathrm{CO}_{2}$, microbial activity, hydrocarbon flux and available nucleation sites/templates (Walter 1986; Aloisi et al. 2000; Peckmann et al. 2001; Lopez et al. 2009; Roberts et al. 2010; Krause et al. 2012; Roberts et al. 2013; Panieri et al. 2017b).

The crust samples from the Hola trough are predominantly aragonite, whereas the carbonate nodules from within the sediment column are mostly cemented by dolomite (Fig. 9). This difference in seep carbonate mineralogy has been observed and reported previously and is ascribed to the different formation environments (e.g. Aloisi et al. 2000; Greinert et al. 2001). Generally, aragonite-dominated seep carbonates 
found close to the seafloor were interpreted as the result of higher sulphate concentration which favours the precipitation of aragonite over the precipitation of calcite/high-Mg calcite/dolomite (Baker and Kastner 1981; Bohrmann et al. 1998; Aloisi et al. 2000; Aloisi et al. 2002; Han et al. 2004; Teichert et al. 2005; Haas et al. 2010; Crémière et al. 2016b). A recent study of carbonate-associated-sulphate (CAS) in authigenic carbonates supports the theory of aragonite formation close to the seafloor based on $\delta 34 \mathrm{~S}$ and $\delta 18 \mathrm{O}$ of sulphate and Sr isotope data (Feng et al. 2016). High-Mg calcite and dolomite, on the other hand, are favourably precipitated at low sulphate concentrations when the sulphate-methane transition zone (SMTZ) occurs deeper within the sediment (Greinert et al. 2001; Moore et al. 2004; Gieskes et al. 2005; Meister et al. 2007; Pierre and Fouquet 2007) or in association with pore waters exhibiting different $\mathrm{Ca} / \mathrm{Mg}$ ratios than seawater (e.g. Crémière et al. 2012). The mechanism by which sulphate can influence the carbonate mineralogy is related to ion complexing, where the $\mathrm{Mg} 2+$ and $\mathrm{SO} 42$ - ions form strongly bonded ion pairs (and weaker $\mathrm{Ca}-\mathrm{SO} 4$ ion bonds). This process increases $\mathrm{Mg}$ solubility, and thus hinders dolomite precipitation. Vice versa, dolomite precipitation can be promoted by sulphate removal through sulphatereducing bacteria (SRB) (Baker and Kastner 1981; Slaughter and Hill 1991; Wright and Wacey 2004). Furthermore, a study by Zhang et al. (2012) found that dissolved sulphide at concentration levels of a few millimoles, often found in sediment pore water where bacterial sulphate reduction coupled to AOM is active (Fig. 10), can promote the crystallization of disordered dolomite.

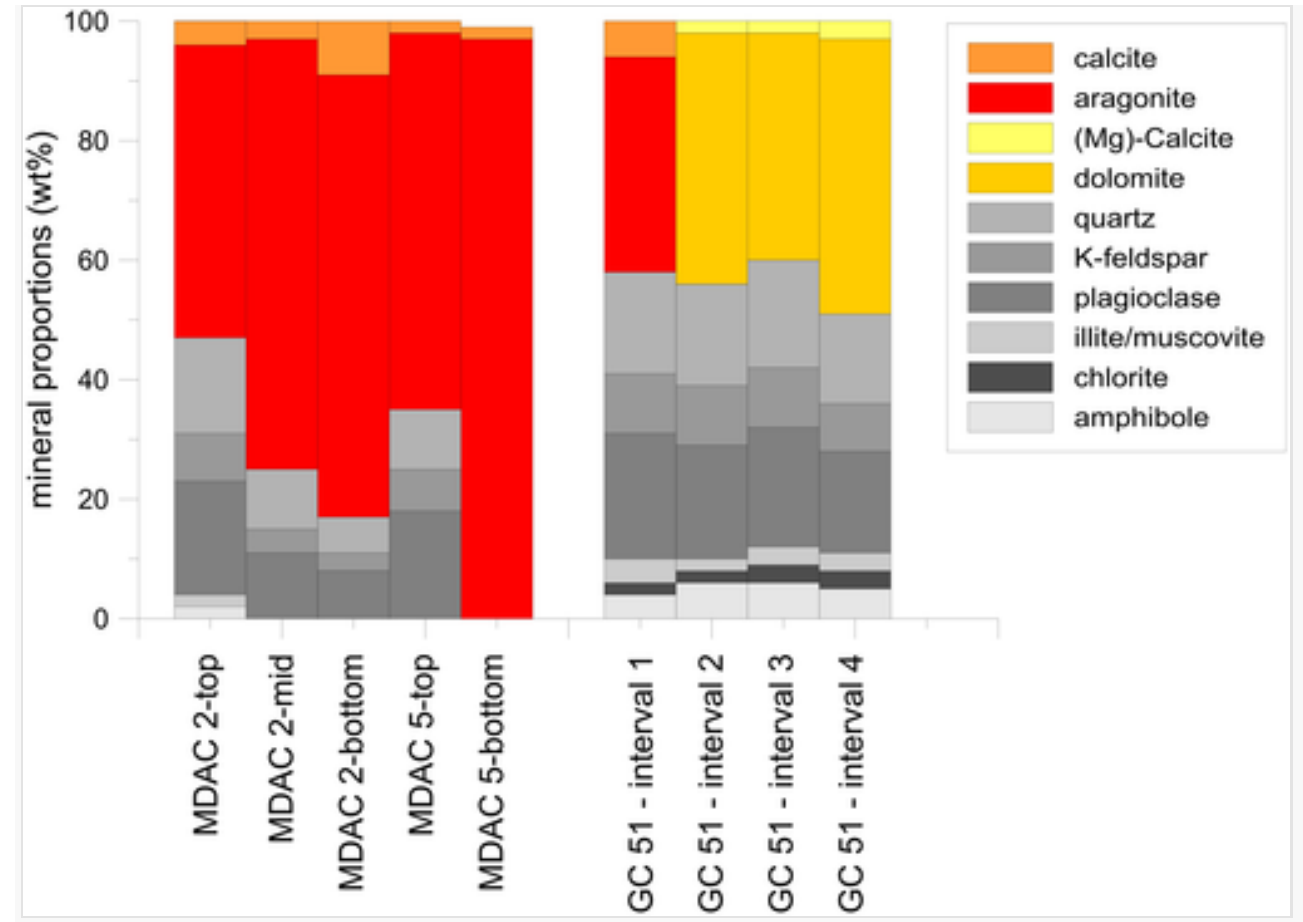

Fig. 9 Results of mineral quantification using XRD for MDAC crust samples 2 and 5 and carbonate nodules from core GC 51.

At our study site we thus interpret aragonite-dominated samples MDAC 2 and 5 and the crust piece from core GC 51 interval 1 to be precipitated in an environment close to the seafloor where sulphate-rich seawater/pore water was present and $\mathrm{PO}_{4}{ }^{3-}$ concentrations were low. To achieve precipitation close to the seafloor a high methane flux is required. The presence of the MDAC crusts above the seafloor today is the result of erosion by high-velocity bottom currents in the Hola trough (Bøe et al. 2009). In contrast, the dolomite nodules of interval 2-4 (Fig. 6), coinciding with high sedimentary $\mathrm{Ca} / \mathrm{Ti}$ values, are interpreted to have formed deeper within the sediment at or close to the SMTZ in an environment more restricted from seawater influence, lower sulphate concentrations and higher dissolved sulphide concentrations. Dolomite precipitation in low methane flux settings has also been described e.g. from Hydrate Ridge (Greinert et al. 2001), but other studies also find high-Mg calcite precipitation (instead of dolomite) in methane-rich sediments (Naehr et al. 2007; Lim et al. 2009; Nöthen and Kasten 2011). We cannot ascertain which factor exactly favoured dolomite over HMC precipitation at our study site, but suppose that it could be the pore water Mg/Ca ratio (e.g. Feng et al. 2014b). 


\subsubsection{Stable oxygen isotopes}

The $\delta^{18} \mathrm{O}$ values of MDAC have been widely used to retrieve information on fluids involved in the precipitation of carbonates such as gas hydrate-derived water, clay dehydration water or seawater (Bohrmann et al. 1998; Aloisi et al. 2000; Han et al. 2004; Bahr et al. 2009; Haas et al. 2010; Bian et al. 2013; Feng et al. 2014a; Mazzini et al. 2016). Evaluation of $\delta^{18} \mathrm{O}$ signatures of MDAC requires knowledge of the ambient water temperature during formation, carbonate mineralogy and the $\delta^{18} \mathrm{O}$ of the ascending fluid. We calculated the $\delta^{18} \mathrm{O}$ of the fluid from which our carbonate samples precipitated assuming equilibrium isotopic fractionation, using the present bottom water temperature of $6.5^{\circ}{ }^{\circ} \mathrm{C}$ (Sauer et al. 2015). For the MDAC samples, we only used the micro-drilled samples of presumably pure aragonite and compared the results of two different equations from the literature (Grossman and Ku 1986; Kim et al. 2007b). Resulting $\delta^{18} \mathrm{O}$ of the precipitating fluid varied between - 0.1\%o and 0.3\% (SMOW, Grossman and Ku 1986) and between 0.6\%oand 1.0\% (SMOW, Kim et al. 2007b) (Table S3). For the dolomite nodules, the $\delta^{18} \mathrm{O}$ (SMOW) values of the precipitating fluid varied between $0.1 \%$ and $0.5 \%$ (Table S3) (Vasconcelos et al. 2005). The present seawater $\delta^{18} \mathrm{O}$ values show regional differences but the global data set of LeGrande and Schmidt (2006) suggests a value around 0\% (SMOW) on the Norwegian margin. As seawater $\delta^{18} \mathrm{O}$ between the LGM and present day has varied between ca. $1 \%$ and $0 \%$ SMOW (Fairbanks 1989), we interpret the aragonite of the MDAC samples and the dolomite nodules to have precipitated close to equilibrium with seawater isotopic composition. Although the results of the two different equations for the aragonite samples vary by around $0.7 \%$, they are still all within the range of equilibrium precipitation, especially considering that bottom water temperatures also can have varied increasing the uncertainties of our $\delta^{18} \mathrm{O}_{\text {fluid }}$ estimates. Thus, we infer that probably no fluids from dissociating gas hydrates were involved in the formation of the dolomite nodules or the aragonite crusts. The $\delta^{18} \mathrm{O}$ values of other MDAC crusts from the Norwegian margin (Nyegga Pockmark G11) have also been interpreted to reflect the formation in equilibrium with seawater (Chevalier et al. 2010). The absence of gas hydrate influence is in line with modelling results suggesting that our study area in the Hola trough is outside the gas hydrate stability field at present (Vogt et al. 1999; Crémière et al. 2016a).

\subsubsection{Carbon isotope signatures of MDAC}

The distinct difference between aragonitic carbonate crusts at the seafloor and the dolomitic carbonate nodules within the sediment column is also reflected in their carbon isotopic composition (Fig.7b). The $\delta^{13} \mathrm{C}$ values of aragonite-dominated MDAC crusts (both micro-drilled and bulk samples) (average ca. $-29.5 \%$ ) are around $18 \%$ o lower than those of the dolomite nodules (average ca. $-12 \%$ o) (Fig. $7 \mathrm{~b}$ ). The aragonite crust piece from interval-1 in core GC 51, however, can be grouped with MDAC 2 and 5 from a mineralogical point of view, but based on its $\delta^{13} \mathrm{C}$-carbonate value it falls in the same field as the dolomite nodules, i.e. with heavier $\delta^{13} \mathrm{C}$ values up to $-9 \%$ (Fig. $7 \mathrm{~b}$ ).

Several carbon sources are generally considered for the formation of authigenic carbonate. The isotopically lightest carbon derives from the oxidation of methane via AOM. In the Hola trough $\delta^{13} \mathrm{C}$ of methane from sediment samples was found to be ar ound-55\%o (VBDP) (Sauer et al. 2015) and predominantly of thermogenic origin. Another source is dissolved inorganic carbon (DIC) from the degradation of organic matter. Average $\delta^{13} \mathrm{C}$ of organic carbon from core GC 51 is - 25\%o (VPDB) (Sauer et al. 2016), which would produce DIC with almost the same carbon isotope composition (Presley and Kaplan 1968). However, organic carbon content in Hola sediments is only $0.5 \mathrm{wt} \%$ on average and degradation rates by sulphate reduction are rather low (Sauer et al. 2016) implying that organic matter degradation is not adding significant amounts to the DIC pool. Seawater $\delta^{13} \mathrm{C}$-DIC of ca. $0 \%$ (Walter et al. 2007) might be an additional source of isotopically heavier carbon for the authigenic carbonates. Higher $\delta^{13} \mathrm{C}$-DIC values may be a result of methanogenesis (producing ${ }^{13} \mathrm{C}$-enriched DIC) or derived from deeper fluids influenced by anaerobic hydrocarbon biodegradation and secondary methanogenesis (e.g. Crémière et al. 2013). This has been suggested for $\delta^{13} \mathrm{C}$ values as high as $+14 \%$ (PDB) in carbonates reported by Dimitrakopoulos and Muehlenbachs (1987). Sauer et al. (2016) considered deep-sourced DIC influenced by secondary methanogenesis as a reason for pore water DIC values of up to $+18 \%$ o (VPDB) in Hola sediments (GC 51) below the SMTZ which also can be incorporated during authigenic carbonate formation. A quantification of the relative contribution from different carbon sources to the formation of the authigenic carbonates in the Hola trough is difficult based only on the $\delta^{13} \mathrm{C}$ values because there are more than two possible sources. Nevertheless, we suggest that MDAC samples 2 and 5 with $\delta^{13} \mathrm{C}$ values as low as $-35 \%$ indicate a higher contribution of methane-derived carbon. We support this inference by mineralogical evidence of aragonite precipitation close to the seafloor, which requires a shallow SMTZ and high methane flux, and thus high rates of AOM. In contrast, dolomite nodules from GC 51 with much higher $\delta^{13} \mathrm{C}$ values of around - 12\% presumably formed deeper within the sediment at lower methane fluxes 
and lower AOM rates than the MDAC crusts and, thus, incorporated less methane-derived carbon. We suggest the contribution of DIC from methanogenesis or deep fluid sources as the carbon source responsible for those higher $\delta^{13} \mathrm{C}$ values, rather than the influence of seawater. This was inferred from the $\delta^{13} \mathrm{C}$-DIC at the present SMTZ in core GC 51 (-12\%o, Sauer et al. 2015) (Fig. 10), showing the same $\delta^{13} \mathrm{C}$ value as the dolomite nodules, suggesting a mix of DIC sources from AOM and methanogenesis and/or deep fluids (Sauer et al. 2016).

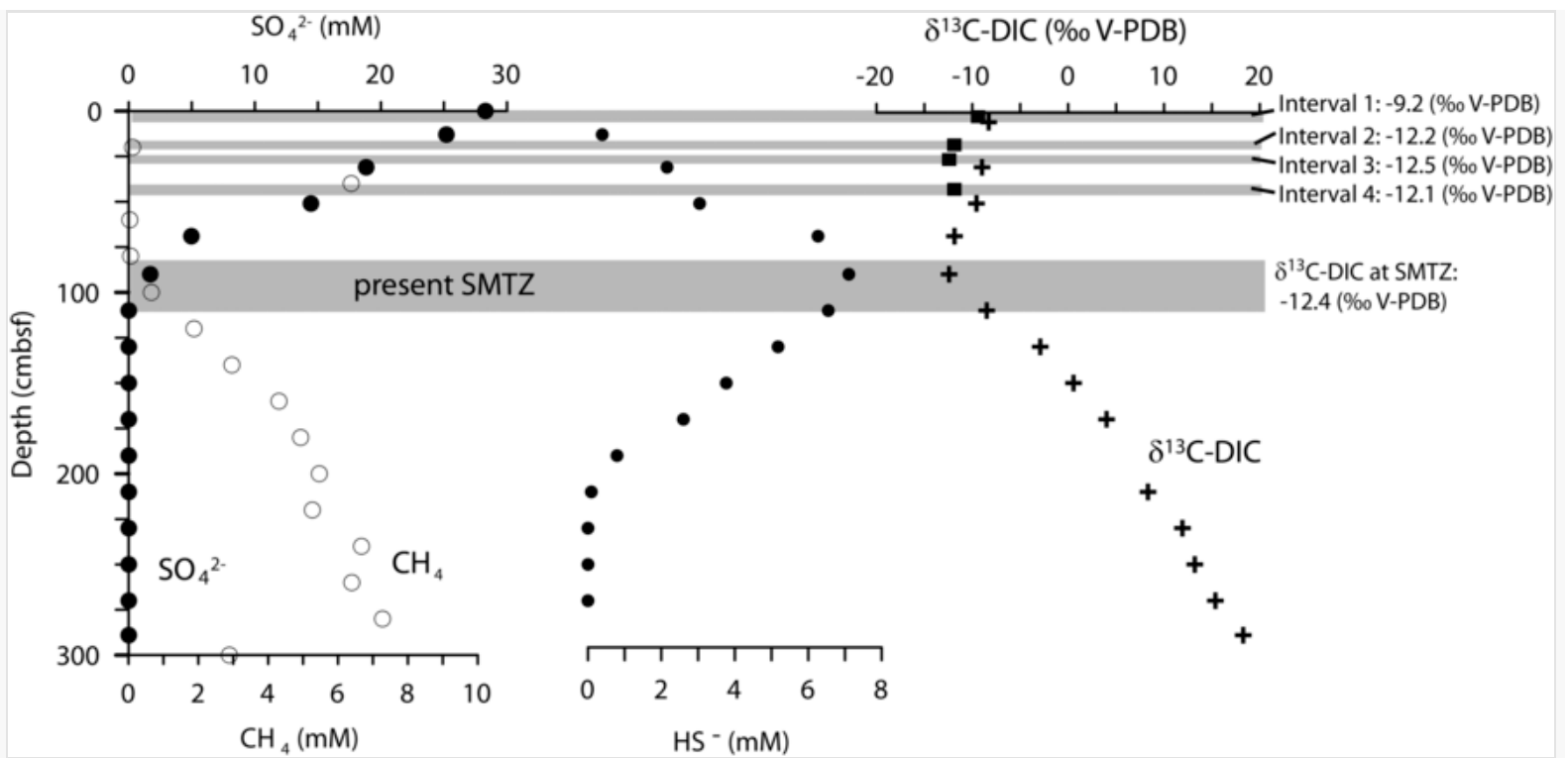

Fig. 10 Pore water profiles of core GC 51 including sulphate, methane and dissolved sulphide concentrations, and the $\delta^{13} \mathrm{C}$ of dissolved inorganic carbon (DIC) (Sauer et al. 2015). The thin grey bars indicate the intervals of authigenic carbonates (including their $\delta^{13} \mathrm{C}$ values marked as black squares), the thick grey bar shows the present depth of the sulphate-methane transition zone (SMTZ).

\subsubsection{Lipid biomarkers}

To study the involvement of AOM consortia in the formation of authigenic carbonates we analysed the concentration and compound specific isotope composition of known biomarkers for archaea (the diphytanylglycerol diethers archaeol (Ar) and sn-2-hydroxyarchaeol (OH-Ar) (Kate 1993)) and SRB (iand ai- $\mathrm{C}_{15: 0}$ fatty acid) that have been found in connection with AOM activity (Aloisi et al. 2002; Bahr et al. 2009; Gontharet et al. 2009; Guan et al. 2016). Ar is a common membrane lipid of archaea and is associated to $\mathrm{AOM}$ if it shows very low $\delta^{13} \mathrm{C}$ values indicating the utilization of methane-derived carbon (e.g. Elvert et al. 2000). OH-Ar with very low $\delta^{13} \mathrm{C}$ values has also been found at various cold seep settings indicating AOM (Elvert et al. 2000, and references therein). Most of the AOM relevant archaea are assigned to two distinct phylogenetic clusters, ANME-1 and ANME-2 (Orphan et al. 2002; Blumenberg et al. 2004) where high ratios of $\mathrm{OH}-\mathrm{Ar} / \mathrm{Ar}$ point to the ANME 2 group archaea (Blumenberg et al. 2004; Elvert et al. 2005).

In our samples MDAC 2 and MDAC 5, high concentrations of Ar and OH-Ar were found with very low $\delta^{13} \mathrm{C}$ values between - 103\%o and - 108\%, which clearly indicates the involvement of AOM-performing archaea during MDAC formation. Furthermore, the high $\mathrm{OH}-\mathrm{Ar} / \mathrm{Ar}$ ratio (1.7, Table 3) in both samples suggests a predominance of ANME 2 archaea (Blumenberg et al. 2004; Elvert et al. 2005) which corroborates findings from MDACs from the Norwegian margin (Nyegga Pockmark G11) (Chevalier et al. 2010). Moreover, we find high concentrations of bacterial lipids, the $i$ - and ai-branched $C_{15: 0}$ fatty acids, in our MDAC 2 and 5 samples, which indicate the presence of SRB (e.g. Hinrichs and Boetius 2003) which have been found in virtually all AOM environments (Niemann and Elvert 2008, and references therein). In combination with the low $\delta^{13} \mathrm{C}$ values (- 62 to - 91\%) of these two compounds (although less ${ }^{13} \mathrm{C}$-depleted than the archaeal lipids, Table 3) we infer that the SRB are part of the AOM-performing microbial consortium and that, thus, sulphate-dependant AOM has led to the precipitation of MDAC 2 and 5. The compounds $i$ - and $a i-C_{15: 0}$ showed a similar $\delta^{13} \mathrm{C}$ range of $-99 \%$ to $-55 \%$ in Marmara sea cold seep sediments (Chevalier et al. 2013), and were also found in an MDAC crust from the Nyegga Pockmark (Chevalier et al. 2010). Furthermore, the ratio between $i$ - and $a i-\mathrm{C}_{15: 0}$ can indicate SRB types (Niemann and Elvert 2008). A lower value of this ratio $(<2)$, as found in our samples (0.7-0.9), suggests a Seep- 
SRB1/ANME-2 consortium which is consistent with the $\mathrm{OH}-\mathrm{Ar} / \mathrm{Ar}$ ratios found in our MDAC samples suggesting ANME-2.

Comparing the concentration of Ar and OH-Ar between the samples of sediment core GC 51 and the MDAC 2 and MDAC 5 samples reveals a difference of more than an order of magnitude for Ar, and two orders of magnitude for OH-Ar (Table 3, Fig. 6). The concentrations of AOM biomarkers show a relationship with AOM rate (Elvert et al. 2005), thus indicating significantly higher AOM rates during the formation of the MDAC crusts than within the sediment column at site GC 51. Furthermore, $\delta^{13} \mathrm{C}$ of bulk organic matter extracted from the crusts is as low as $-60 \%$, whereas the most negative value of $\delta^{13} \mathrm{C}$ of sedimentary organic matter from GC 51 is $-26 \%$ (Sauer et al. 2016) supporting a high fraction of methanotrophic biomass in the MDAC samples.

Apart from low $\delta^{13} \mathrm{C}$ values of AOM biomarkers in MDAC 2 and 5, we found other indications for the involvement of microbes performing AOM in the formation of the MDAC crusts. The microscopic investigations revealed that the whitish clotted aragonite in MDAC 2 and 5 (opaque in transmitted light) probably contains organic remains. Clotted aragonite has been previously found to contain high concentration of organic matter (Himmler et al. 2010), and fossilized microbial filaments (Teichert et al. 2005) which could be remains of AOM consortia. This is supported by a study of Leefmann et al. (2008) which found that $>90 \%$ (by weight) of AOM specific biomarkers are present in the whitish clotted aragonite of MDACs and that these represent fossilized biofilms of AOM consortia. This is consistent with the photomicrographs of our samples showing that the clotted aragonite associates with microbial structures that also form the origin of radial aragonite growth (Fig. 4a-4).

\subsubsection{Carbonate nodules as palaeo-SMTZ indicators?}

The present SMTZ in core GC 51 is located at $80-110 \mathrm{~cm}$ below seafloor (Sauer et al. 2015). A peak in the $\mathrm{Ca} / \mathrm{Ti}$ profile in core GC 51 suggests that there is authigenic carbonate precipitation induced by AOM between 80 and $85 \mathrm{~cm}$ (Fig. 6). The activity of AOM is also supported by a peak in Ar concentration and the presence of $\mathrm{OH}-\mathrm{Ar}$ in this depth interval (Fig. 6).

Even higher concentrations of $\mathrm{Ar}, \mathrm{OH}-\mathrm{Ar}$, the largest peak in $\mathrm{Ca} / \mathrm{Ti}$ and the biggest dolomite nodules (Interval 4) were found between 40 and $50 \mathrm{~cm}$ depth which we interpret as the former location of the SMTZ (Fig. 6). The SMTZ was probably stable at this location longer than it has been at its current location providing the time to accumulate larger amounts of lipid biomarkers of methanotrophic archaea and authigenic dolomite. The location of the former and the present SMTZ is also supported by peaks in the $\mathrm{Ba} / \mathrm{Ti}$ ratio around $10-15 \mathrm{~cm}$ above each of the SMTZ intervals (Fig. 6). Barium fronts in the form of authigenic barite are known to form just above the SMTZ when barium-rich fluids from below get in contact with sulphate (Torres et al. 1996a; Torres et al. 1996b; Dickens 2001; Riedinger et al. 2006; Kasten et al. 2012). Also the barium fronts suggest that the SMTZ was stable at 40-50 cm (Interval 4) longer than it has been at its current depth due to a much more pronounced $\mathrm{Ba} / \mathrm{Ti}$ peak (Ba-front).

The dolomite nodules, which are present at 20-26 cm sediment depth (Interval 2 and 3), might also indicate a former SMTZ location, but there were no AOM-related biomarkers found in the sediment in that interval (Fig. 6). We do not have a satisfactory explanation for this observation yet; however, it is possible that the dolomite nodules themselves contain the AOM-biomarkers, but not the sediment around them. Unfortunately, the dolomite nodules did not provide enough material to determine lipid biomarker concentrations. Other possibilities are that the dolomite nodules in this interval were not formed at the SMTZ, or microbial biomarkers for AOM that were present originally were not preserved, or the SMTZ was not stable at this location long enough to accumulate a detectable amount of the biomarkers.

Based on the (at least) two different depth intervals of the SMTZ, we infer that at site GC 51 there was an abrupt decrease in methane flux shifting the SMTZ downward from 40 to $50 \mathrm{~cm}$ to a present location of 80-110 cm. Given the erosional regime at site GC 51 at present (Bøe et al. 2009), another mechanism that could have moved the SMTZ downward in the sediment column is the removal of sediment at the surface through high bottom currents. However, we favour an abrupt change in methane flux as an explanation because the shift between SMTZ intervals is very pronounced. Erosion at the surface would probably have caused a more gradual change in SMTZ depth not providing enough time for the formation of authigenic carbonate nodules and overlying $\mathrm{Ba}$ fronts at pronounced intervals.

Regarding the time of formation of the dolomite nodules, we cannot provide exact dates of precipitation due to the lack of U-Th ages for these samples. The best estimate is based on ${ }^{14} \mathrm{C}$ sediment ages 
determined for core GC 51 (Sauer et al. 2016) which provides maximum ages for the nodule formation. This approach places dolomite nodule formation in the Holocene.

\subsection{Timing of MDAC formation and potential driving processes}

To improve the time constraints on past methane seepage in the Hola trough we performed U-Th dating on the MDAC samples 2 and 5. Our age results of both crusts range between 1.6 and $4.4 \mathrm{ka} \mathrm{BP}$ which is significantly younger than a Hola sample previously dated by Crémière et al. (2016a) (6-11.3 ka BP) (Fig. 11). No specific upward or downward precipitation trend within the crusts can be deduced from our dating results (Fig. 8). The only chronologic trend is the progressively younger ages of aragonite linings within the cavities. (MDAC 5: age8 $\rightarrow$ age7, MDAC 2: age4 $\rightarrow$ age 3). Our estimated carbonate precipitation rate of $5.3 \mathrm{~mm} / \mathrm{ka}$ from one of the aragonite linings appears slow compared to other studies that find rates between 4 and $50 \mathrm{~mm} / \mathrm{ka}$ in a crust from the Nile deep-sea fan (Bayon et al. 2009), around 10 $20 \mathrm{~mm} / \mathrm{ka}$ in the Barents Sea (Crémière et al. 2016a), $48 \mathrm{~mm} / \mathrm{ka}$ in a theoretical study of carbonate precipitation (Luff et al. 2004), and approximately $470 \mathrm{~mm} / \mathrm{ka}$ for a carbonate build-up in the northern Arabian Sea (Himmler et al. 2016).
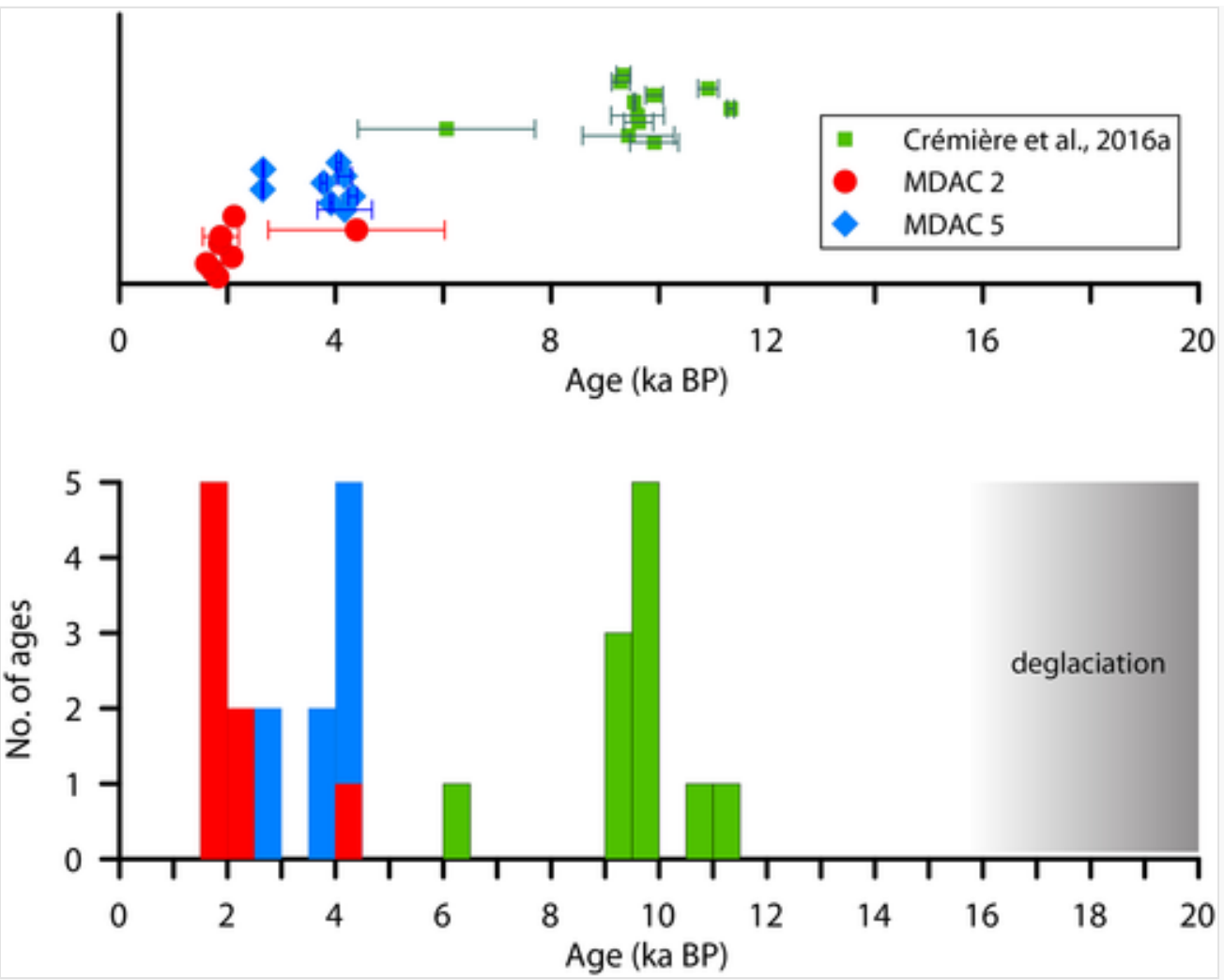

Fig. 11 Compilation of U-Th dating results of samples MDAC 2 and MDAC 5 from this study and published results on one sample from the Hola trough (Crémière et al. 2016a).

A study by Crémière et al. (2016a) focussing on MDAC samples from the Barents Sea, reports ages suggesting a main crust-forming episode between 17 and $7 \mathrm{ka}$. They attribute the onset of enhanced methane seepage to the dissociation of gas hydrates below the disintegrating Barents Sea ice sheet during the last deglaciation. On the Vesterålen shelf the main phase of deglaciation took place between 19 ka and 16 ka BP (Vorren et al. 2015; Stroeven et al. 2016). Thus, there appears to be a rather large time gap of around $5 \mathrm{ka}$ between the removal of the ice sheet and the start of the main phase of methane seepage recorded by the carbonate precipitation in the Hola trough (11 ka BP, (Crémière et al. 2016a)). However, we cannot determine the exact onset of carbonate formation/methane seepage because the dating results are restricted to later-stage cavity infills of aragonite and, hence, there is no time constraint on early-stage carbonate cement formation. Modelling of gas hydrate stability during the LGM shows that the Hola trough was very close to the border of the gas hydrate stability field suggesting only small amounts of gas hydrates trapped in the sediments on the Vesterålen shelf during the LGM (Crémière et al. 2016a). These indications together 
with our $\delta^{18} \mathrm{O}$ values of aragonite and dolomite samples suggest no involvement of gas hydrate water in the formation of the carbonate crusts and nodules at the Hola trough seep site during the Holocene. Alternatively, episodes of increased seismicity and earthquakes in this area of the Norwegian margin may have caused methane seepage and periods of MDAC formation due to changes in pore pressure and/or the re-activation of faults causing fluid flow (Jonsson et al. 2003). A compilation of seismicity since 1880 (Byrkjeland et al. 2000) shows higher seismic activity on the Lofoten-Vesterålen margin and the Nordland coast which might have been caused by remaining glacioisostatic adjustments and/or the large scale Pliocene/Pleistocene erosion causing stress fields due to sedimentary loading and unloading (Olesen et al. 2013). According to Stroeven et al. (2016 and references therein), the highest rates of deglaciation of the Fennoscandian Ice Sheet occurred at 11-10 ka BP, probably also inducing strongest post-glacial seismicity around that time (Bungum et al. 2005). The timing coincides with the ages determined for the crust from the Hola trough (ca. 10 ka) studied by Crémière et al. (2016a) (Fig. 11) and could be explained by methane seepage as a consequence of fault re-activation or pore pressure changes leading to open conduits for fluid flow from potential reservoirs to the seabed. Furthermore, clustering of ages of MDAC 5 around 4 ka BP (Fig. 11) suggests that MDAC formation occurred around the time when a submarine landslide took place around $250 \mathrm{~km}$ to the SW of the Hola trough initiated at the shelf break at the mouth of the Trænadjupet trough (Laberg and Vorren 2000). The most recent study on the Trænadjupet slide suggests an age around $4 \mathrm{ka}$ BP based on ${ }^{14} \mathrm{C}$ dating of sediment cores (Allin et al. 2016). The most likely trigger for this slide is assumed to be one bigger earthquake or several smaller ones (Laberg and Vorren 2000), probably related to postglacial rebound induced seismicity. We suggest that the MDAC 5 sample could have formed due to enhanced methane seepage that was caused by the same seismicity pulse. Thus, two of the three dated MDAC samples from the Hola trough can tentatively be related to seismic events. To our knowledge, sample MDAC 2 with ages clustering around 2 ka cannot yet be correlated to any known seismic event in Northern Norway.

Two other known submarine landslides, the Andøya Slide, which is located even closer to our study area in a northern direction, and the giant Storegga Slide are also inferred to have occurred during the Holocene. The main Storegga slide was dated to $8100 \pm 250$ cal years. BP (Haflidason et al. 2005), whereas no temporal constraints on the Andøya slide exist yet, except for a Holocene age (Laberg et al. 2000). Both slides have also been linked to earthquake activity (Laberg et al. 2000; Bryn et al. 2005). This supports the notion of several higher-seismicity periods on the Norwegian margin during the Holocene, or alternatively a rather constant state of higher seismicity during the whole Holocene.

Considering that all three dated MDAC samples from the Hola trough show different time spans, there is the potential for sampling bias in interpreting enhanced methane escape and carbonate formation events. The question remains if the age clusters around 2 ka, 4 ka and $10 \mathrm{ka} \mathrm{BP} \mathrm{(Fig.} \mathrm{11)} \mathrm{represent} \mathrm{distinct}$ events of enhanced methane seepage, or if there was rather constant and continuous methane seepage throughout the Holocene. However, to answer this question with more certainty requires dating of more MDAC samples from the Hola trough.

If our U-Th ages represent temporally constrained events of enhanced methane seepage, the different MDAC crust patches could be interpreted as the result of changing fluid conduits due to reactivation of different faults, or by clogging of preferred fluid pathways by carbonate precipitation, which forced the fluids to find different pathways to the sediment surface. On the other hand, the fact that this area in the Hola trough is still an active methane seep site (Chand et al. 2008; Sauer et al. 2015) could also indicate that it has been continuously active for around 10 ka now. The results of the U-Th dating of the MDAC crusts from different fields suggest that the methane flux at least was varying spatially. The change in SMTZ depth at site GC 51 inferred from intervals of authigenic dolomite nodules and archaeal biomarker patterns in the sediments furthermore support the temporal variation of methane flux at this location. Probably, these changes were rather abrupt followed by a constant flux for some time to enable a pronounced interval of authigenic dolomite precipitation in the sediments, rather than dispersed carbonate precipitation due to a slowly changing SMTZ.

\section{Summary}

In this study from the northern Norwegian shelf, we describe two types of methane-derived authigenic carbonates: large aragonite-cemented crusts found on the seabed, and centimetre-size dolomitecemented nodules found in several intervals in the upper $50 \mathrm{~cm}$ of a sediment core (Table 4).

Table 4 Summary of main characteristics of the two different types of methane-derived carbonates found in the Hola trough seep area. 


\begin{tabular}{|c|c|c|}
\hline & Carbonate crusts & Carbonate nodules \\
\hline Dominant mineral & aragonite & dolomite \\
\hline $\begin{array}{l}\text { average } \delta^{13} \mathrm{C} \text {-carbonate } \\
\text { (VPDB) }\end{array}$ & $-29 \%$ & $-12 \%$ \\
\hline \multirow[t]{3}{*}{ Carbon source } & $\mathrm{AOM}$ & $\mathrm{AOM}$ \\
\hline & Seawater & Deep fluid/methanogenesis \\
\hline & & (Seawater) \\
\hline \multirow[t]{2}{*}{ Methane flux } & High & \multirow[t]{2}{*}{ Lower } \\
\hline & $\rightarrow$ Higher rates of AOM & \\
\hline \multirow[t]{2}{*}{$\delta^{18} \mathrm{O}$ fluid (VSMOW) } & -0.1 to $0.9 \%$ & $0.1=0.5 \%$ \\
\hline & No gas hydrate influence & No gas hydrate influence \\
\hline \multirow[t]{2}{*}{ Formation } & 1.6-4.4 ka BP (this study) & \multirow[t]{2}{*}{ Holocene } \\
\hline & (ca. 10 ka BP, (Crémière et al. 2016a)) & \\
\hline \multirow[t]{3}{*}{ Conclusion } & \multicolumn{2}{|c|}{ Spatial and temporal variation of methane escape over the last $11 \mathrm{ka}$} \\
\hline & \multicolumn{2}{|c|}{$\begin{array}{l}\text { Probably in relation to seismicity induced re-activation of faults or pore pressure } \\
\text { changes causing fluid flow }\end{array}$} \\
\hline & \multicolumn{2}{|c|}{$\begin{array}{l}\text { Correlation with post-glacial uplift-induced seismicity and earthquake-induced } \\
\text { submarine landslides }\end{array}$} \\
\hline
\end{tabular}

The crusts are composed of early-stage microcrystalline aragonite cementing detrital sediments and bioclasts and later-stage cryptocrystalline and botryoidal, lucent aragonite occurring as cavity fillings. The nodules are composed of microcrystalline dolomite cementing detrital sediments and bioclasts. The distinct carbonate mineralogy of crusts and nodules probably reflects different formation environments. Aragonitecemented crusts were likely formed close to the seafloor under greater influence of seawater and high AOM rates, whereas dolomite nodules probably formed deeper within the sediment at or close to the SMTZ under less seawater-influenced conditions and lower AOM rates.

The ${ }^{13} \mathrm{C}$ depleted carbon isotope composition of aragonite crusts (average $\delta^{13} \mathrm{C}-30 \%$ ) indicates the involvement of AOM in the carbonate formation. The dolomite nodules exhibit less ${ }^{13} \mathrm{C}$ depletion $\left(\delta^{13} \mathrm{C}\right.$ values around - 12\%o) which under other circumstances might not have been interpreted as AOM-induced carbonate formation. In our case, however, including information from pore water $\delta^{13} \mathrm{C}$ - DIC (Sauer et al., 2015) and SMTZ depth reconstruction we also interpret the formation of dolomite nodules as a result of AOM. This highlights the limitations of using only $\delta^{13} \mathrm{C}$-carbonate values to determine carbon sources of authigenic carbonates. In our samples, a stronger ${ }^{13} \mathrm{C}$ depletion in aragonite $\left(\delta^{13} \mathrm{C}\right.$ on average $20 \%$ o lower than dolomite) suggests a larger fraction of methane-derived carbon and thus higher rates of AOM during aragonite formation. This is further supported by high concentrations of archaeol and sn-2-hydroxyarchaeol in carbonate crust samples and a $\delta^{13} \mathrm{C}$ value of bulk organic carbon as low as - 60\%o suggesting a 
considerable amount of methanotrophic biomass within the crusts. Moreover, microscope investigations reveal microbial structures in the late stage aragonite precipitates probably representing organic remains.

U-Th dating of two MDAC crusts from this study integrated with the geochronology of a previously published Hola MDAC crust (Crémière et al. 2016a) suggests that methane seepage periods and related carbonate formation took place between 10 and $2 \mathrm{ka} \mathrm{BP.} \mathrm{The} \mathrm{clustering} \mathrm{of} \mathrm{ages} \mathrm{of} \mathrm{two} \mathrm{of} \mathrm{the} \mathrm{crusts} \mathrm{correlates}$ with periods of enhanced seismic activity: 10 ka BP (Crémière et al. 2016a) is tentatively correlated with highest rates of ice retreat during the final stage of deglaciation of the Fennoscandian Ice Sheet and, thus, highest seismicity induced by isostatic crustal rebound, while at around 4 ka BP a submarine landslide occurred south of our study area which was likely triggered by earthquake activity. Hence, we consider a relationship between periods of higher seismicity and enhanced methane flux and carbonate precipitation along the northern Norwegian margin.

\section{Acknowledgements}

We thank the captain and the crew of RV Helmer Hanssen and RV G.O. Sars including the chief scientists Matthias Forwick and Rolf Birger Pedersen for the support and assistance during research cruises. We are grateful to Elin Sagvold from Geosystems for assisting with carbonate crust sawing and to the NGU laboratory for chemical analyses. We thank Serge Robert and Nemiah Ladd from EAWAG for lipid biomarker analyses. We thank Dr. Barbara Teichert and two anonymous reviewers for their constructive comments, which helped us to improve the manuscript. The authors acknowledge funding from RWE-Dea (now Dea Norge AS) (C-1648/1) and from the Norwegian Research Council through its Centres of Excellence funding scheme (project number 223259) for CAGE-Centre for Arctic Gas Hydrate, Environment and Climate, Department of Geosciences, UiT, The Arctic University of Norway, Tromsø, Norway, and Petromaks2 NORCRUST - Norwegian margin fluid systems and methane-derived authigenic carbonate crusts (project number 255150).

\section{Appendix A. Supplementary data}

Supplementary data to this article can be found online
at http://dx.doi.org/10.1016/j.chemgeo.2017.09.004.

\section{References}

Aharon P., Schwarcz H.P. and Roberts H.H., Radiometric dating of submarine hydrocarbon seeps in the Gulf of Mexico, Geol. Soc. Am. Bull. 109 (5), 1997, 568-579.

Allin, J., Mozzato, A., Tappin, D., Talling, P., and Hunt, J., Were the Trænadjupet and Nyk Slides multi-staged? In: Proceedings EGU General Assembly Conference Abstracts 2016, Volume 18, p. 2144.

Aloisi G., Pierre C., Rouchy J.-M., Foucher J.-P., and Woodside J., Methane-related authigenic carbonates of eastern Mediterranean Sea mud volcanoes and their possible relation to gas hydrate destabilisation, Earth Planet. Sci. Lett. 184 (1), 2000, 321-338.

Aloisi G., Bouloubassi I., Heijs S.K., Pancost R.D., Pierre C., Sinninghe Damsté J.S., Gottschal J.C., Forney L.J. and Rouchy J.-M., $\mathrm{CH}_{4}$-consuming microorganisms and the formation of carbonate crusts at cold seeps, Earth Planet. Sci. Lett. 203 (1), 2002, 195-203.

Bahr A., Pape T., Bohrmann G., Mazzini A., Haeckel M., Reitz A. and Ivanov M., Authigenic carbonate precipitates from the NE Black Sea: a mineralogical, geochemical, and lipid biomarker study, Int. J. Earth Sci. 98 (3), 2009, 677-695.

Baker P.A. and Kastner M., Constraints on the formation of sedimentary dolomite, Science 213 (4504), 1981, 214-216.

Bayon G., Henderson G.M. and Bohn M., U-Th stratigraphy of a cold seep carbonate crust, Chem. Geol. 260 (12), 2009, 47-56.

Bayon G., Dupre S., Ponzevera E., Etoubleau J., Cheron S., Pierre C., Mascle J., Boetius A. and de Lange G.J., Formation of carbonate chimneys in the Mediterranean Sea linked to deep-water oxygen depletion, Nat. Geosci. 6 (9), 2013, 755-760. 
Bayon G., Henderson G.M., Etoubleau J., Caprais J.-C., Ruffine L., Marsset T., Dennielou B., Cauquil E., Voisset M. and Sultan N., U-Th isotope constraints on gas hydrate and pockmark dynamics at the Niger delta margin, Mar. Geol. 370, 2015, 87-98.

Bellec V., Bøe R., Thorsnes T., Rise L., Dolan M., Elvenes S., Lepland A. and Selboskar O.H., Geologisk Havbunnskart, Kart 6183001400, In: Norges geologiske undersøkelse, 2012.

Bergh S.G., Eig K., Kløvjan O.S., Henningsen T., Olesen O. and Hansen J.A., The Lofoten-Vesterålen continental margin: a multiphase Mesozoic-Palaeogene rifted shelf as shown by offshore-onshore brittle fault-fracture analysis, Nor. J. Geol. 87, 2007, 29-58.

Berndt C., Feseker T., Treude T., Krastel S., Liebetrau V., Niemann H., Bertics V.J., Dumke I., Dünnbier K., Ferré B., Graves C., Gross F., Hissmann K., Hühnerbach V., Krause S., Lieser K., Schauer J. and Steinle L., Temporal constraints on hydrate-controlled methane seepage off Svalbard, Science 343 (6168), 2014, 284-287.

Bian Y., Feng D., Roberts H.H. and Chen D., Tracing the evolution of seep fluids from authigenic carbonates: Green Canyon, northern Gulf of Mexico, Mar. Pet. Geol. 44, 2013, 71-81.

Blumenberg M., Seifert R., Reitner J., Pape T. and Michaelis W., Membrane lipid patterns typify distinct anaerobic methanotrophic consortia, Proc. Natl. Acad. Sci. U. S. A. 101 (30), 2004, 11111-11116.

Blumenberg M., Walliser E.-O., Taviani M., Seifert R. and Reitner J., Authigenic carbonate formation and its impact on the biomarker inventory at hydrocarbon seeps - a case study from the Holocene Black Sea and the Plio-Pleistocene Northern Apennines (Italy), Marine and Petroleum Geology 66 (Part 3), 2015, 532_ 541.

Blystad P., Brekke H., Færseth R.B., Larsen B.T., Skogseid J. and Tørudbakken B., Structural elements of the Norwegian continental shelf, Norw. Petrol. Direct. Bull. 8, 1995, 1-45.

Bøe R., Bellec V.K., Dolan M.F.J., Buhl-Mortensen P., Buhl-Mortensen L., Slagstad D. and Rise L., Giant sandwaves in the Hola glacial trough off Vesterålen, North Norway, Mar. Geol. 267 (1-2), 2009, 36-54.

Boetius A., Ravenschlag K., Schubert C.J., Rickert D., Widdel F., Gieseke A., Amann R., Jorgensen B.B., Witte U. and Pfannkuche O., A marine microbial consortium apparently mediating anaerobic oxidation of methane, Nature 407 (6804), 2000, 623-626.

Bohrmann G., Greinert J., Suess E. and Torres M., Authigenic carbonates from the Cascadia subduction zone and their relation to gas hydrate stability, Geology 26 (7), 1998, 647-650.

Brendryen J., Haflidason H., Rise L., Chand S., Vanneste M., Longva O., L'Heureux J.S. and Forsberg C.F., Ice sheet dynamics on the Lofoten-Vesterålen shelf, north Norway, from Late MIS-3 to Heinrich Stadial 1, Quat. Sci. Rev. 119, 2015, 136-156.

Bryn P., Berg K., Forsberg C.F., Solheim A. and Kvalstad T.J., Explaining the Storegga slide, Mar. Pet. Geol. 22 (1-2), 2005, 11-19.

Bungum H., Lindholm C. and Faleide J.I., Postglacial seismicity offshore mid-Norway with emphasis on spatiotemporal-magnitudal variations, Mar. Pet. Geol. 22 (1-2), 2005, 137-148.

Byrkjeland U., Bungum H. and Eldholm O., Seismotectonics of the Norwegian continental margin, J. Geophys. Res. Solid Earth 105 (B3), 2000, 6221-6236.

Chand S., Rise L., Bellec V., Dolan M., Bøe R., Thorsnes T. and Buhl-Mortensen P., Active venting system offshore Northern Norway, EOS Trans. Am. Geophys. Union 89 (29), 2008, 261-262.

Cheng H., Lawrence Edwards R., Shen C.-C., Polyak V.J., Asmerom Y., Woodhead J., Hellstrom J., Wang Y., Kong X., Spötl C., Wang X. and Calvin Alexander Jr E., Improvements in ${ }^{230} \mathrm{Th}$ dating, ${ }^{230} \mathrm{Th}$ and ${ }^{234} \mathrm{U}$ half-life values, and U-Th isotopic measurements by multi-collector inductively coupled plasma mass spectrometry, Earth Planet. Sci. Lett. 371-372, 2013, 82-91.

Chevalier N., Bouloubassi I., Stadnitskaia A., Taphanel M.-H., Lorre A., Damsté J.S. and Pierre C., Distributions and carbon isotopic compositions of lipid biomarkers in authigenic carbonate crusts from the Nordic margin (Norwegian Sea), Org. Geochem. 41 (9), 2010, 885-890. 
Chevalier N., Bouloubassi I., Birgel D., Taphanel M.H. and Lopez-Garcia P., Microbial methane turnover at Marmara Sea cold seeps: a combined 16S rRNA and lipid biomarker investigation, Geobiology 11 (1), 2013, 55-71.

Crémière A., Pierre C., Blanc-Valleron M.-M., Zitter T., Çăgatay M.N. and Henry P., Methane-derived authigenic carbonates along the North Anatolian fault system in the Sea of Marmara (Turkey), Deep-Sea Res. I Oceanogr. Res. Pap. 66, 2012, 114-130.

Crémière A., Bayon G., Ponzevera E. and Pierre C., Paleo-environmental controls on cold seep carbonate authigenesis in the Sea of Marmara, Earth Planet. Sci. Lett. 376 (0), 2013, 200-211.

Crémière A., Lepland A., Chand S., Sahy D., Condon D.J., Noble S.R., Martma T., Thorsnes T., Sauer S. and Brunstad H., Timescales of methane seepage on the Norwegian margin following collapse of the Scandinavian Ice Sheet, Nat. Commun. 7, 2016a, 11509.

Crémière A., Lepland A., Chand S., Sahy D., Kirsimae K., Bau M., Whitehouse M.J., Noble S.R., Martma T., Thorsnes T. and Brunstad H., Fluid source and methane-related diagenetic processes recorded in cold seep carbonates from the Alvheim channel, central North Sea, Chem. Geol. 432, 2016b, 16-33.

Dickens G.R., Sulfate profiles and barium fronts in sediment on the Blake Ridge: present and past methane fluxes through a large gas hydrate reservoir, Geochim. Cosmochim. Acta 65 (4), 2001, 529-543.

Dimitrakopoulos R. and Muehlenbachs K., Isotopes in the sedimentary cycle Biodegradation of petroleum as a source of ${ }^{13} \mathrm{C}$-enriched carbon dioxide in the formation of carbonate cement, Chemical Geology: Isotope Geoscience section 65 (3), 1987, 283-291.

Elvert M., Suess E., Greinert J. and Whiticar M.J., Archaea mediating anaerobic methane oxidation in deep-sea sediments at cold seeps of the eastern Aleutian subduction zone, Org. Geochem. 31 (11), 2000, 11751187.

Elvert M., Hopmans E.C., Treude T., Boetius A. and Suess E., Spatial variations of methanotrophic consortia at cold methane seeps: implications from a high-resolution molecular and isotopic approach, Geobiology 3 (3), 2005, 195-209.

Elvsborg A., Late Quaternary sedimentation in a glacial trough on the continental shelf off Troms, northern Norway, Nor. Geol. Tidsskr. 59, 1979, 309-325.

Færseth R.B., Structural development of the continental shelf offshore Lofoten-Vesterålen, northern Norway, Nor. J. Geol. 92, 2012, 19-40.

Fairbanks R.G., A 17,000-year glacio-eustatic sea level record: influence of glacial melting rates on the Younger Dryas event and deep-ocean circulation, Nature 342 (6250), 1989, 637-642.

Feng D., Chen D., Peckmann J. and Bohrmann G., Authigenic carbonates from methane seeps of the northern Congo fan: microbial formation mechanism, Mar. Pet. Geol. 27 (4), 2010, 748-756.

Feng D., Birgel D., Peckmann J., Roberts H.H., Joye S.B., Sassen R., Liu X.-L., Hinrichs K.-U., and Chen D., Time integrated variation of sources of fluids and seepage dynamics archived in authigenic carbonates from Gulf of Mexico Gas Hydrate Seafloor Observatory, Chem. Geol. 385, 2014a, 129-139.

Feng D., Roberts H.H., Joye S.B. and Heydari E., Formation of low-magnesium calcite at cold seeps in an aragonite sea, Terra Nova 26 (2), 2014b, 150-156.

Feng D., Peng Y.B., Bao H.M., Peckmann J., Roberts H.H. and Chen D.F., A carbonate-based proxy for sulfatedriven anaerobic oxidation of methane, Geology 44 (12), 2016, 999-1002.

Fischer D., Mogollón J.M., Strasser M., Pape T., Bohrmann G., Fekete N., Spiess V. and Kasten S., Subduction zone earthquake as potential trigger of submarine hydrocarbon seepage, Nat. Geosci. 6 (8), 2013, 647-651.

Gieskes J., Mahn C., Day S., Martin J.B., Greinert J., Rathburn T. and McAdoo B., A study of the chemistry of pore fluids and authigenic carbonates in methane seep environments: Kodiak Trench, Hydrate Ridge, Monterey Bay, and Eel River Basin, Chem. Geol. 220 (3-4), 2005, 329-345.

Gontharet S., Stadnitskaia A., Bouloubassi I., Pierre C. and Damsté J.S.S., Palaeo methane-seepage history traced by biomarker patterns in a carbonate crust, Nile deep-sea fan (Eastern Mediterranean Sea), Mar. Geol. 261 (1-4), 2009, 105-113. 
Greinert J., Bohrmann G. and Suess E., Gas hydrate-associated carbonates and methane-venting at hydrate ridge: classification, distribution, and origin of authigenic lithologies, natural gas hydrates: occurrence, distribution, and detection, Am. Geophys. Union 2001, 99-113.

Grossman E.L. and Ku T.-L., Oxygen and carbon isotope fractionation in biogenic aragonite: Temperature effects, Chemical Geology: Isotope Geoscience section 59, 1986, 59-74.

Guan H., Zhang M., Mao S., Wu N., Lu H. and Chen D., Methane seepage in the Shenhu area of the northern South China Sea: constraints from carbonate chimneys, Geo-Mar. Lett. 2016, 1-12.

Haas A., Peckmann J., Elvert M., Sahling H. and Bohrmann G., Patterns of carbonate authigenesis at the Kouilou pockmarks on the Congo deep-sea fan, Mar. Geol. 268 (1-4), 2010, 129-136.

Haflidason H., Lien R., Petter Sejrup H., Forsberg C.F. and Bryn P., The dating and morphometry of the Storegga Slide, In: Ormen Lange-an Integrated Study for Safe Field Development in the Storegga Submarine Area, 2005, Elsevier; Oxford, 123-136.

Han X., Suess E., Sahling H. and Wallmann K., Fluid venting activity on the Costa Rica margin: new results from authigenic carbonates, Int. J. Earth Sci. 93 (4), 2004, 596-611.

Himmler T., Bach W., Bohrmann G. and Peckmann J., Rare earth elements in authigenic methane-seep carbonates as tracers for fluid composition during early diagenesis, Chem. Geol. 277 (1-2), 2010, 126-136.

Himmler T., Birgel D., Bayon G., Pape T., Ge L., Bohrmann G. and Peckmann J., Formation of seep carbonates along the Makran convergent margin, northern Arabian Sea and a molecular and isotopic approach to constrain the carbon isotopic composition of parent methane, Chem. Geol. 415, 2015, 102-117.

Himmler T., Bayon G., Wangner D., Enzmann F., Peckmann J. and Bohrmann G., Seep-carbonate lamination controlled by cyclic particle flux, Sci Rep 6, 2016, 37439.

Hinrichs K.-U. and Boetius A., The anaerobic oxidation of methane: new insights in microbial ecology and biogeochemistry, In: Wefer G., et al., (Eds.), Ocean Margin Systems, 2003, Springer Berlin Heidelberg; Berlin, Heidelberg, 457-477.

Hinrichs K.-U., Hayes J.M., Sylva S.P., Brewer P.G. and DeLong E.F., Methane-consuming archaebacteria in marine sediments, Nature 398 (6730), 1999, 802-805.

Hong W.L., Torres M.E., Carroll J., Cremiere A., Panieri G., Yao H. and Serov P., Seepage from an arctic shallow marine gas hydrate reservoir is insensitive to momentary ocean warming, Nat. Commun. 8, 2017, 15745 .

Hovland M., Talbot M., Olaussen S. and Aasberg L., Recently formed methane- derived carbonates from the North Sea floor, In: Thomas B.M., (Ed), Petroleum Geochemistry in Exploration of the Norwegian Shelf, 1985, Springer Netherlands, 263-266.

Hovland M., Talbot M.R., Qvale H., Olaussen S. and Aasberg L., Methane-related carbonate cements in pockmarks of the North Sea, J. Sediment. Res. 57 (5), 1987, 881-892.

Hovland M., Svensen H., Forsberg C.F., Johansen H., Fichler C., Fosså J.H., Jonsson R. and Rueslåtten H., Complex pockmarks with carbonate-ridges off mid-Norway: products of sediment degassing, Mar. Geol. 218 (1-4), 2005, 191-206.

Jonsson S., Segall P., Pedersen R. and Bjornsson G., Post-earthquake ground movements correlated to porepressure transients, Nature 424 (6945), 2003, 179-183.

Judd A.G. and Hovland M., Seabed fluid flow, 2007, Cambridge University Press; New York.

Kasten S., Nöthen K., Hensen C., Spieß V., Blumenberg M. and Schneider R.R., Gas hydrate decomposition recorded by authigenic barite at pockmark sites of the northern Congo Fan, Geo-Mar. Lett. 32 (5-6), 2012, 515-524.

Kate M., Chapter 9 Membrane lipids of archaea, In: Kates D.J.K. and Matheson A.T., (Eds.), M, 1993, Elsevier; New Comprehensive Biochemistry, 261-295.

Kim S.-T., Mucci A. and Taylor B.E., Phosphoric acid fractionation factors for calcite and aragonite between 25 and $75^{\circ} \mathrm{C}$ : revisited, Chem. Geol. 246 (3-4), 2007a, 135-146. 
Kim S.-T., O'Neil J.R., Hillaire-Marcel C. and Mucci A., Oxygen isotope fractionation between synthetic aragonite and water: influence of temperature and $\mathrm{Mg}^{2+}$ concentration, Geochim. Cosmochim. Acta $\mathbf{7 1}$ (19), 2007b, 4704-4715.

Krause S., Liebetrau V., Gorb S., Sánchez-Román M., McKenzie J.A. and Treude T., Microbial nucleation of Mgrich dolomite in exopolymeric substances under anoxic modern seawater salinity: new insight into an old enigma, Geology 40 (7), 2012, 587-590.

Kutterolf S., Liebetrau V., Mörz T., Freundt A., Hammerich T. and Garbe-Schönberg D., Lifetime and cyclicity of fluid venting at forearc mound structures determined by tephrostratigraphy and radiometric dating of authigenic carbonates, Geology 36 (9), 2008, 707.

Laberg J.S. and Vorren T.O., The Trænadjupet Slide, offshore Norway — morphology, evacuation and triggering mechanisms, Mar. Geol. 171 (1-4), 2000, 95-114.

Laberg J.S., Vorren T.O., Dowdeswell J.A., Kenyon N.H. and Taylor J., The Andøya Slide and the Andøya Canyon, north-eastern Norwegian-Greenland Sea, Mar. Geol. 162 (2-4), 2000, 259-275.

Leefmann T., Bauermeister J., Kronz A., Liebetrau V., Reitner J. and Thiel V., Miniaturized biosignature analysis reveals implications for the formation of cold seep carbonates at Hydrate Ridge (off Oregon, USA), Biogeosciences 5 (3), 2008, 731-738.

LeGrande A.N. and Schmidt G.A., Global gridded data set of the oxygen isotopic composition in seawater, Geophys. Res. Lett. 33 (12), 2006, L12604.

Liebetrau V., Eisenhauer A. and Linke P., Cold seep carbonates and associated cold-water corals at the Hikurangi Margin, New Zealand: new insights into fluid pathways, growth structures and geochronology, Mar. Geol. 272 (1-4), 2010, 307-318.

Lim D., Choi J., Xu Z., Kim M., Choi D., Jung H. and Lee P., Methane-derived authigenic carbonates from the Ulleung basin sediments, East Sea of Korea, Cont. Shelf Res. 29 (13), 2009, 1588-1596.

Loeseth H. and Tveten E., Post-Caledonian structural evolution of the Lofoten and Vesteralen offshore and onshore areas, Nor. J. Geol. 76, 1996, 215-230.

Lopez O., Zuddas P. and Faivre D., The influence of temperature and seawater composition on calcite crystal growth mechanisms and kinetics: implications for $\mathrm{Mg}$ incorporation in calcite lattice, Geochim. Cosmochim. Acta 73 (2), 2009, 337-347.

Løseth H., Paleogeographical evolution of the Lofoten and Vesterålen onshore and offshore area, In: Geonytt, Abstract Volume, 1999, 71-72.

Lu Y., Sun X., Lin Z., Xu L., Gong J. and Lu H., Cold seep status archived in authigenic carbonates: mineralogical and isotopic evidence from Northern South China Sea, Deep-Sea Res. II Top. Stud. Oceanogr. 122, 2015, 95-105.

Luff R., Wallmann K. and Aloisi G., Numerical modeling of carbonate crust formation at cold vent sites: significance for fluid and methane budgets and chemosynthetic biological communities, Earth Planet. Sci. Lett. 221 (1-4), 2004, 337-353.

Mackey E.A., Christopher S.J., Licndstrom R.M., Long S.E., Marlow A.F., Murphy K.E., Paul R.L., PopelkaFilcoff R.S., Rabb S.A. and Sieber J.R., Certification of three NIST renewal soil standard reference materials for element content: SRM 2709a San Joaquin Soil, SRM 2710a Montana Soil I, and SRM 2711a Montana Soil II, NIST Spec. Publ. 260, 2010, 172.

Marlow J.J., Steele J.A., Ziebis W., Thurber A.R., Levin L.A. and Orphan V.J., Carbonate-hosted methanotrophy represents an unrecognized methane sink in the deep sea, Nat. Commun. 5, 2014, 5094.

Mazzini A., Svensen H., Hovland M. and Planke S., Comparison and implications from strikingly different authigenic carbonates in a Nyegga complex pockmark, G11, Norwegian Sea, Mar. Geol. 231 (1-4), 2006, 89-102.

Mazzini A., Svensen H.H., Planke S., Forsberg C.F. and Tjelta T.I., Pockmarks and methanogenic carbonates above the giant Troll gas field in the Norwegian North Sea, Mar. Geol. 373, 2016, $26-38$. 
Meister P., McKenzie J.A., Vasconcelos C., Bernasconi S., Frank M., Gutjahr M. and Schrag D.P., Dolomite formation in the dynamic deep biosphere: results from the Peru Margin, Sedimentology 54 (5), 2007, 1007-1032.

Moore T.S., Murray R.W., Kurtz A.C. and Schrag D.P., Anaerobic methane oxidation and the formation of dolomite, Earth Planet. Sci. Lett. 229 (1-2), 2004, 141-154.

Naehr T.H., Eichhubl P., Orphan V.J., Hovland M., Paull C.K., Ussler Iii W., Lorenson T.D. and Greene H.G., Authigenic carbonate formation at hydrocarbon seeps in continental margin sediments: a comparative study, Deep-Sea Res. II Top. Stud. Oceanogr. 54 (11-13), 2007, 1268-1291.

Niemann H. and Elvert M., Diagnostic lipid biomarker and stable carbon isotope signatures of microbial communities mediating the anaerobic oxidation of methane with sulphate, Org. Geochem. 39 (12), 2008, 1668-1677.

Nöthen K. and Kasten S., Reconstructing changes in seep activity by means of pore water and solid phase Sr/Ca and Mg/Ca ratios in pockmark sediments of the Northern Congo Fan, Mar. Geol. 287 (1-4), 2011, 1-13.

Olesen O., Bungum H., Dehls J.F., Lindholm C., Pascal C. and Roberts D., Neotectonics, seismicity and contemporary stress field in Norway - mechanisms and implications, In: Olsen L., Fredin O. and Olesen O., (Eds.), Quaternary Geology of Norway. Geological Survey of Norway Special Publication, 2013, 145174.

Orphan V.J., House C.H., Hinrichs K.-U., McKeegan K.D. and DeLong E.F., Methane-consuming archaea revealed by directly coupled isotopic and phylogenetic analysis, Science 293 (5529), 2001, 484-487.

Orphan V.J., House C.H., Hinrichs K.-U., McKeegan K.D. and DeLong E.F., Multiple archaeal groups mediate methane oxidation in anoxic cold seep sediments, Proc. Natl. Acad. Sci. 99 (11), 2002, 7663-7668.

Ottesen D., Dowdeswell J.A., Rise L., Rokoengen K. and Henriksen S., Large-scale morphological evidence for past ice-stream flow on the mid-Norwegian continental margin, Geol. Soc. Lond., Spec. Publ. 203 (1), 2002, 245-258.

Ottesen D., Dowdeswell J.A. and Rise L., Submarine landforms and the reconstruction of fast-flowing ice streams within a large Quaternary ice sheet: the 2500-km-long Norwegian-Svalbard margin (57-80 N), Geol. Soc. Am. Bull. 117 (7-8), 2005, 1033-1050.

Panieri G., Bünz S., Fornari D.J., Escartin J., Serov P., Jansson P., Torres M.E., Johnson J.E., Hong W., Sauer S., Garcia R. and Gracias N., An integrated view of the methane system in the pockmarks at Vestnesa Ridge, 79² N, Mar. Geol. 390, 2017a, 282-300.

Panieri G., Lepland A., Whitehouse M.J., Wirth R., Raanes M.P., James R.H., Graves C.A., Crémière A. and Schneider A., Diagenetic Mg-calcite overgrowths on foraminiferal tests in the vicinity of methane seeps, Earth Planet. Sci. Lett. 458, 2017b, 203-212.

Peckmann J. and Thiel V., Carbon cycling at ancient methane-seeps, Chem. Geol. 205 (3-4), $2004,443-467$.

Peckmann J., Reimer A., Luth U., Luth C., Hansen B.T., Heinicke C., Hoefs J. and Reitner J., Methane-derived carbonates and authigenic pyrite from the northwestern Black Sea, Mar. Geol. 177 (1-2), 2001, 129-150.

Pierre C. and Fouquet Y., Authigenic carbonates from methane seeps of the Congo deep-sea fan, Geo-Mar. Lett. 27 (2-4), 2007, 249-257.

Presley B.J. and Kaplan I.R., Changes in dissolved sulfate, calcium and carbonate from interstitial water of nearshore sediments, Geochim. Cosmochim. Acta 32 (10), 1968, 1037-1048.

Riedinger N., Kasten S., Gröger J., Franke C. and Pfeifer K., Active and buried authigenic barite fronts in sediments from the Eastern Cape Basin, Earth Planet. Sci. Lett. 241 (3-4), 2006, 876-887.

Ritger S., Carson B. and Suess E., Methane-derived authigenic carbonates formed by subduction-induced porewater expulsion along the Oregon/Washington margin, Geol. Soc. Am. Bull. 98 (2), 1987, 147-156.

Roberts H.H., Feng D. and Joye S.B., Cold-seep carbonates of the middle and lower continental slope, northern Gulf of Mexico, Deep-Sea Res. II Top. Stud. Oceanogr. 57 (21), 2010, 2040-2054. 
Roberts J.A., Kenward P.A., Fowle D.A., Goldstein R.H., González L.A. and Moore D.S., Surface chemistry allows for abiotic precipitation of dolomite at low temperature, Proc. Natl. Acad. Sci. 110 (36), 2013, 14540-14545.

Robinson L.F., Belshaw N.S. and Henderson G.M., U and Th concentrations and isotope ratios in modern car bonates and waters from the Bahamas, Geochim. Cosmochim. Acta 68 (8), 2004, 1777-1789.

Römer M., Sahling H., Pape T., dos Santos Ferreira C., Wenzhöfer F., Boetius A. and Bohrmann G., Methane fluxes and carbonate deposits at a cold seep area of the Central Nile Deep Sea Fan, Eastern Mediterranean Sea, Mar. Geol. 347, 2014, 27-42.

Rosenbaum J. and Sheppard S.M.F., An isotopic study of siderites, dolomites and ankerites at high temperatures, Geochim. Cosmochim. Acta 50 (6), 1986, 1147-1150.

Sauer S., Knies J., Lepland A., Chand S., Eichinger F. and Schubert C.J., Hydrocarbon sources of cold seeps off the Vesterålen coast, northern Norway, Chem. Geol. 417, 2015, 371-382.

Sauer S., Hong W.-L., Knies J., Lepland A., Forwick M., Klug M., Eichinger F., Baranwal S., Crémière A., Chand S. and Schubert C.J., Sources and turnover of organic carbon and methane in fjord and shelf sediments off northern Norway, Geochem. Geophys. Geosyst. 17 (10), 2016, 4011-4031.

Slaughter M. and Hill R.J., The influence of organic matter in organogenic dolomitization, J. Sediment. Res. 61 (2), 1991, 296-303.

Stroeven A.P., Hättestrand C., Kleman J., Heyman J., Fabel D., Fredin O., Goodfellow B.W., Harbor J.M., Jansen J.D., Olsen L., Caffee M.W., Fink D., Lundqvist J., Rosqvist G.C., Strömberg B. and Jansson K.N., Deglaciation of Fennoscandia, Quat. Sci. Rev. 147, 2016, 91-121.

Teichert B.M.A., Eisenhauer A., Bohrmann G., Haase-Schramm A., Bock B. and Linke P., U/Th systematics and ages of authigenic carbonates from Hydrate Ridge, Cascadia Margin: recorders of fluid flow variations, Geochim. Cosmochim. Acta 67 (20), 2003, 3845-3857.

Teichert B.M.A., Bohrmann G. and Suess E., Chemoherms on Hydrate Ridge — Unique microbially-mediated carbonate build-ups growing into the water column, Palaeogeogr. Palaeoclimatol. Palaeoecol. 227(1-3), 2005, 67-85.

Tong H., Feng D., Cheng H., Yang S., Wang H., Min A.G., Edwards R.L., Chen Z. and Chen D., Authigenic carbonates from seeps on the northern continental slope of the South China Sea: new insights into fluid sources and geochronology, Mar. Pet. Geol. 43, 2013, 260-271.

Torres M.E., Bohrmann G. and Suess E., Authigenic barites and fluxes of barium associated with fluid seeps in the Peru subduction zone, Earth Planet. Sci. Lett. 144 (3), 1996a, 469-481.

Torres M.E., Brumsack H.J., Bohrmann G. and Emeis K.C., Barite fronts in continental margin sediments: a new look at barium remobilization in the zone of sulfate reduction and formation of heavy barites in diagenetic fronts, Chem. Geol. 127 (1), 1996b, 125-139.

Vasconcelos C., McKenzie J.A., Warthmann R. and Bernasconi S.M., Calibration of the $\delta^{18} \mathrm{O}$ paleothermometer for dolomite precipitated in microbial cultures and natural environments, Geology 33 (4), 2005.

Vogt R.P., Gardner J. and Crane K., The Norwegian-Barents-Svalbard (NBS) continental margin: introducing a natural laboratory of mass wasting, hydrates, and ascent of sediment, pore water, and methane, Geo-Mar. Lett. 19 (1), 1999, 2-21.

Vorren T.O., Rydningen T.A., Baeten N.J. and Laberg J.S., Chronology and extent of the Lofoten-Vesterålen sector of the Scandinavian Ice Sheet from 26 to 16 cal. ka BP, Boreas 44 (3), 2015, 445-458.

Walter L.M., Relative efficiency of carbonate dissolution and precipitation during diagenesis: a progress report on the role of solution chemistry, In: Gautier G.L., (Ed), Roles of Organic Matter in Mineral Diagenesis, 1986, Society of Economic Palaeontologists and Mineralogists, Special Publications, 1-12.

Walter L.M., Ku T.C.W., Muehlenbachs K., Patterson W.P. and Bonnell L., Controls on the $\delta^{13} \mathrm{C}$ of dissolved inorganic carbon in marine pore waters: an integrated case study of isotope exchange during syndepositional recrystallization of biogenic carbonate sediments (South Florida Platform, USA), DeepSea Res. II 54 (11-13), 2007, 1163-1200. 
Watanabe Y., Nakai S.i., Hiruta A., Matsumoto R. and Yoshida K., U-Th dating of carbonate nodules from methane seeps off Joetsu, eastern margin of Japan Sea, Earth Planet. Sci. Lett. 272 (1-2), 2008, 89-96.

Westbrook G.K., Thatcher K.E., Rohling E.J., Piotrowski A.M., Pälike H., Osborne A.H., Nisbet E.G., Minshull T.A., Lanoisellé M., James R.H., Hühnerbach V., Green D., Fisher R.E., Crocker A.J., Chabert A., Bolton C., Beszczynska-Möller A., Berndt C. and Aquilina A., Escape of methane gas from the seabed along the West Spitsbergen continental margin, Geophys. Res. Lett. 36 (15), 2009, L15608.

Wright D.T. and Wacey D., Sedimentary dolomite: a reality check, Geol. Soc. Lond., Spec. Publ. 235 (1), 2004, 65-74.

Zhang F., Xu H., Konishi H., Kemp J.M., Roden E.E. and Shen Z., Dissolved sulfide-catalyzed precipitation of disordered dolom ite: implications for the formation mechanism of sedimentary dolomite, Geochim. Cosmochim. Acta 97, 2012, 148-165. 